\title{
Globalization, Economic Freedom and Human Rights
}

\author{
Axel Dreher \\ Martin Gassebner \\ Lars-H. R. Siemers
}

Georg-August-Universität Göttingen 


\title{
Globalization, Economic Freedom and Human Rights
}

\author{
Axel Dreher $^{\text {a }}$ \\ Martin Gassebner ${ }^{\text {b }}$ \\ Lars-H. R. Siemers ${ }^{c}$
}

October 2010

\begin{abstract}
Using the KOF Index of Globalization and two indices of economic freedom, we empirically analyze whether globalization and economic liberalization affect governments' respect for human rights using a panel of 106 countries over the 1981-2004 period. According to our results, physical integrity rights significantly and robustly increase with globalization and economic freedom, while empowerment rights are not robustly affected. Due to the lack of consensus about the appropriate level of empowerment rights as compared to the outright rejection of any violation of physical integrity rights, the global community is presumably less effective in promoting empowerment rights.
\end{abstract}

Keywords: Human Rights, Globalization, Economic Freedom, Liberalization

JEL-Codes: D78, F55, K10, P48

${ }^{a}$ Georg-August University Goettingen, Platz der Goettinger Sieben 3, 37073 Goettingen, Germany, KOF Swiss Economic Institute, Switzerland, CESifo, and IZA, Germany. Email: mail@axel-dreher.de

b ETH Zurich, KOF Swiss Economic Institute, Weinbergstrasse 35, CH-8092 Zürich, Switzerland, CESifo, Germany. E-mail: gassebner@kof.ethz.ch

${ }^{c}$ RWI Essen - Institute for Economic Research, Hohenzollernstraße 1-3, 45128 Essen, Germany. E-mail: siemers@rwi-essen.de 


\section{Introduction}

At the beginning of the $21^{\text {st }}$ century, governments' disrespect for human rights is still evident in all regions of the world. Human rights violations continue to be the norm rather than the exception. According to Amnesty International (2006), millions of people worldwide are still denied fundamental rights. That being said, governments' respect for human rights is higher in some countries than in others and over the last few decades improvements have been visible in many of these countries. At the same time, globalization and economic freedom has had dramatic consequences on policies and outcomes around the world. ${ }^{1}$ In this paper, we argue that economic freedom and globalization are important determinants of governments' respect for human rights. Competition between economies has become tougher and expanded to an unprecedented worldwide level. Global investors in financial markets exploit even marginal differences in the rates of return and thus generate pressure on local governments. This global development is sometimes viewed as being responsible for disenfranchisement, exploitation, and other forms of human rights abuses (e.g., Rabet 2009). On the other hand, improvements in human rights are sometimes attributed to the spread of liberal ideas, which is one of the key dimensions of globalization (e.g., Rosenau 2003).

We extend the theoretical perspective on the determinants of human rights practice by Poe and Tate (1994) to include globalization and economic freedom. We then empirically investigate whether these aspects actually affect governments' respect for human rights, as measured by the Cingranelli-Richards Human Rights Dataset (CIRI, Cingranelli and Richards 2006). ${ }^{2}$ Our study thus connects to the empirical literature on the determinants of human rights that has emerged through the availability of data on human rights violations.

The question of whether economic globalization affects human rights has been examined previously (Apodaca 2001; Evans 1999; Hafner-Burton 2005; Mitchell and

\footnotetext{
${ }^{1}$ See Dreher et al. (2008) for a comprehensive overview.

${ }^{2}$ The index divides human rights into 13 internationally recognized rights, aggregated to two sublevelsbasic human rights (so called physical integrity rights) and broader civil liberties (i.e., empowerment rights). This allows us to identify the specific effects of these two different categories on human rights.
} 
McCormick 1988; Poe and Tate 1994). ${ }^{3}$ However, in previous studies the influence of globalization has been measured by the extent of capital controls, openness to trade, and the amount of foreign direct investment. From a policy perspective, the influence of all these individual elements of economic globalization on human rights is definitely important. But most elements of economic globalization are highly correlated. Therefore, it is not advisable to include them all independently in one regression. Omitting dimensions on the other hand, causes biased coefficients. Due to a lack of data, the literature has focused on single aspects of economic globalization and human rights, instead of applying a comprehensive approach. Using aggregate indicators of globalization is preferable, because single negative effects could be neutralized by other positive effects, and it is the overall effect of economic globalization that is decisive for an evaluation of its merits. Hence, only an aggregate measure of economic globalization can be used to study the overall effect. We use the economic dimension of the KOF Index of Globalization (Dreher 2006a; Dreher et al. 2008), which aggregates the individual dimensions and allows us to provide the first comprehensive investigation of the effects of economic globalization on human rights violations.

As the KOF Index of Globalization also separates the political and social dimensions of globalization from the economic dimension, we are able to take an even broader perspective and comprehensively analyze the impact of these three distinct dimensions of globalization on human rights.

In addition to external integration and liberalization (globalization), internal economic liberalization has also been discussed as a potentially important determinant of human rights (e.g., Burkhart 2002; Huntington 1968; Marx 2002). Internal economic freedom comprises, for instance, voluntary exchange, free competition, and protection of persons and property within a national economy. Therefore, we also examine the impact of economic freedom on human rights. Again it can be argued that correlation between the variables of interest is important. Given the apparent correlation between economic freedom and the three dimensions of globalization (Bjørnskov 2006), not controlling for economic freedom when investigating the effect of globalization on human rights could bias the results, and vice versa.

\footnotetext{
${ }^{3}$ See also the discussion in Pollis (2004).
} 
In summary, this paper provides the first comprehensive analysis of how economic freedom and the three dimensions of globalization affect governments' respect for human rights. Our empirical analysis puts particular weight on gauging the robustness of the empirical relationship between the variables of interest. Specifically, we employ (variants of) the extreme bounds analysis (EBA), as proposed by Leamer (1983) and Levine and Renelt (1992). We also investigate whether causality does indeed run from globalization and economic freedom to human rights rather than the other way around.

We continue as follows. The next section motivates our control variables, building on the model of Poe and Tate (1994). Section 3 then expands the model and presents our main hypotheses. How we measure human rights, globalization, and economic freedom is outlined in sections 4 and 5. Section 6 describes the method of estimation and our covariates, while the results are shown in section 7. The final section concludes the paper.

\section{The Determinants of Human Rights}

Our starting point for analyzing governments' respect for human rights is the model of Poe and Tate (1994: 855-859), according to which a government's decision to respect human rights is determined by ten variables in six areas: ${ }^{4}$

(i) the level of democracy;

(ii) the level of economic development and its growth rate;

(iii) population size and its growth rate;

(iv) the prevalence of a military and/or leftist regime;

(v) British cultural influence, and

(vi) (recent) experience with international and/or civil war.

In Poe and Tate's model, human rights repression is a tool for governments to solve conflicts. If a government is threatened, it reacts by repressing human rights, for instance, through imprisonment, torture or killings. Since in democracies, processes involve the bargaining of parties, conflicts can be solved in a more peaceful manner compared to

\footnotetext{
${ }^{4}$ Poe and Tate focus on the subset of human rights labeled "integrity of person." However, their theory can easily be generalized for all forms of human rights.
} 
autocracies (Henderson 1991; Poe and Tate 1994). In democracies, repressive governments can be ousted from office in elections. Moreover, the characteristic freedoms in democracies allow citizens to publicize and decry abusive actions. Overall, democracy is expected to improve governments' respect for human rights (see also Davenport and Armstrong 2004). We control for democracy by using the Polity IV index (Marshall and Jaggers 2000). ${ }^{5}$

Regarding economic conditions, Poe and Tate argue that human rights abuses should decrease with economic development, yet increase with economic growth. The better the economic situation, measured by the quantity and quality of goods and services available, the less scarce are goods. Consequently, the potential for conflict, and thus repression, decreases (Mitchell and McCormick 1988; Henderson 1991). The effect of economic growth is less obvious: Since economic growth is the engine of economic development, it should improve human rights practices in a country. However, growth usually involves winners and losers, and may, at least temporarily, increase inequality of income and wealth (Kuznets 1955). As a consequence, social and political tensions rise and the probability of abusive actions increases. To test these theoretical considerations, we employ GDP per capita and GDP growth in our analysis. ${ }^{6}$

Holding resources constant, scarcity of goods (and thus the potential for conflict) is higher in countries with larger populations (Henderson 1991; Poe and Tate 1994). Here the issue of distributing resources fairly among citizens becomes more crucial (Burkhart 2002). Moreover, the number of occurrences of coercive action is likely to be higher in a large population, simply as a matter of numbers. Population growth increases the scarcity of products and resources. Furthermore, rapid population growth increases the percentage of younger people in terms of the total population, which as a group is generally more destabilizing (Poe and Tate 1994). Therefore, both population size and population growth

\footnotetext{
${ }^{5}$ We further account for the level of democracy by controlling for the timing of elections, the age of the state and its political actors, federal states and their representation as well as the presence of special interest executive parties.

${ }^{6}$ As additional variables measuring economic development and growth, we use the Human Development Index, investment, education, proxies for a country's debt level, life expectancy and decentralization measures.
} 
may increase the probability of repressive governmental actions. In addition to these two variables, we incorporate a country's area and urban population in order to control for potential rural-urban differences.

It is more or less a tautology that the probability of repressive actions increases if the country is governed by a repressive regime. Military regimes depend on the power of the armed forces, and conflicts are frequently solved by military order and hierarchy. Hence, military regimes are most likely to control a country through abusive actions and disrespect of human rights whenever possible. Similarly, "leftist regimes," which are defined as socialist or communist governments that do "not allow effective electoral competition with nonsocialist opposition” (Poe and Tate 1994: 858), which is based on the Marxist-Leninist theory that there is a need for the dictatorship of the proletariat, are most likely to show less respect for human rights. Mitchell and McCormick (1988), for instance, provide clear evidence for both hypotheses. We therefore include dummies for socialist legal origin, left-wing governments, and military dictators.

There is also some discussion surrounding the cultural influence of past colonial powers. Mitchell and McCormick (1988) and Burkhart (2002) argue that the colonial experience has prejudiced the shape of present postcolonial political culture, and that the British colonial experience, in contrast to other experiences, was associated with postcolonial development of democracy. British cultural influence in this sense is therefore assumed to involve greater respect for human rights.

Finally, Poe and Tate point out that experience with external or internal war increases the probability of human rights violations. As Burkhart (2002: 158) puts it, civil liberties “disappear in even the most democratic of countries come wartime." We measure war experience with a dummy variable that is equal to 1 if, in a given year, 1000 battlefield casualties occurred as a result of a civil and/or international war.

In addition to these standard variables proposed by Poe and Tate, the current literature has introduced a number of other potential determinants of human rights. The colonial legacy aspect of their model is a potential effect of former globalization. Besides the positive effect of British cultural influence, it can also be argued that Iberian (Spanish and Portuguese) colonies were based on strict hierarchy, authority, absolutism, and twoclass systems, and may therefore be more likely to display a political culture that tolerates 
political repression and human rights violations as a means of maintaining order today (Inglehart 1988). Hence, we also include a variable controlling for Iberian cultural influence. ${ }^{7}$

Another important aspect related to colonialism is religion. The potential difference between Iberian and British influence-if it exists-could originate from different religions. While Orthodox and Roman-Catholic churches have hierarchal and authoritarian structures, these are much less pronounced in Protestant churches. According to the "habituation explanation," proposed by Gurr (1986) and Davenport (1996), Protestant societies may be more tolerant as they have been suppressed by the Catholic mainstream. Arruñada (2010: 895) argues that "Protestants show greater concern for social interactions, in terms of at least social control, rule of law and homogeneity of values.” Using survey data for 32 countries, he finds substantial evidence supporting this "social ethic” hypothesis. Basically, all major religions (in principle) teach peaceful and respectful human interaction. However, different ecclesiastic organization and traditions could affect the average respect its members have for human rights, especially in relation to followers of a different religion. Therefore, we test both whether countries with one dominant religion tend to have more respect for human rights, or if this respect is reduced when minorities are subject to repression.

An aspect which has not yet been directly considered is ethnic fractionalization, as well as other types of societal division. As argued above, the likelihood of a society being fractionalized increases with the size of its population. Moreover, it is obvious that in multiethnic countries (especially when they have only been independent for a short time), the probability of conflict is significantly higher. Illustrative examples are the conflicts and human rights practices in former multiethnic states like the Soviet Union, Yugoslavia, and Czechoslovakia. Divisions of any kind may increase the probability of human rights violations.

Recently, the role of major international organizations and their effects on human rights has come under scrutiny. Abouharb and Cingranelli (2006, 2009) examine the role

\footnotetext{
${ }^{7}$ Besides being a former British colony, we also control for whether the legal origin is British, French, German or Scandinavian. See La Porta et al. (2008) for a detailed summary of the economic consequences of legal origin.
} 
that World Bank and IMF programs play in human rights violations. On the one hand, if the World Bank and the IMF improve economic performance, this could lead to better human rights practices. On the other hand, the conditionality attached to loans from the two institutions could cause hardships and higher levels of domestic conflict, which could then reduce the level of respect for human rights. Abouharb and Cingranelli find that World Bank and IMF involvements deteriorate the human rights situation in borrowing countries. $^{8}$

Huntington's (1968: 41) finding that “[...] causes of violence in [... poor countries] lay with the modernization process rather than with the backwardness itself" addresses another important aspect related to the influence of the level of economic development and growth discussed above, and a potential (indirect) link to economic freedom. In times of transition (modernization), economic freedom increases and the state is reorganized: “As social and economic change broadens, political participation increases, and the demands [...] are greater.” Hence, traditional sources of political authority are challenged. New political institutions are required to channel this newly mobilized citizenry. While these new institutions develop, instability, disorder and corresponding human rights abuses arise. Mitchell and McCormick (1988) assume that both very poor and very rich countries are therefore less likely to have substantial levels of human rights violations, but that those countries in the middle-due to the modernization process they are moving through—are more likely to exhibit patterns of human rights violations. Taking this into account, there should be a non-linear relationship between wealth and respect for human rights. We come back to this in the empirical analysis.

\section{Hypotheses}

On the basis of the previous theoretical and empirical literature, this section derives our hypotheses regarding the link between liberal policies and governments' respect for

\footnotetext{
${ }^{8}$ We complement IMF and World Bank lending variables with the number of human rights NGOs present in a country. Simmons and Danner (2010: 225) demonstrate how ratification of the International Criminal Court (ICC) to prosecute war crimes is a useful step for "some governments to commit to ratchet down violence and get on the road to peaceful negotiations.”
} 
human rights. Our hypotheses comprise two dimensions of freedom, an internal dimension covered by economic freedom within an economy, and an external dimension covered by three dimensions of worldwide integration (globalization). To some extent, both globalization and economic freedom imply a free domestic and a free world market.

\subsection{Globalization and Human Rights Abuses}

Economic, social and political integration can have different effects on the human rights situation in a specific country. The two sub-categories of the human rights measure from Cingranelli and Richards (2006)—physical integrity rights and empowerment rightsmight both be affected in different ways by the three types of globalization. If we neglect this complexity, we will most likely end up with confusing or contradicting results.

As a matter of fact, the literature regarding the relationship between economic globalization and human rights does yield contradicting results. On the one hand, Evans (1999) argues that economic integration in trade and investment generates incentives for governments to abuse poor and disenfranchised people, so that repression, exploitation and human rights abuses arise. On the other hand, Apodaca (2001), Mitchell and McCormick (1988), Poe and Tate (1994) as well as Rosenau (2003) argue that economic integration produces economic wealth, the establishment of the rule of law and a higher respect for human rights and (personal) freedom. Gelleny and McCoy (2001), as well as Mitchell and McCormick (1988), also maintain that due to increased wealth and modernization, global integration leads to a higher level of political stability, so that governments are less tempted to violate human rights to maintain control. Similarly,

Richards et al. (2001) state that globalization forms a "middle-class," which has the power to demand (fundamental) human rights and freedom.

While globalization may increase the size of the pie, according to Rosenau (2003) it may be distributed less equally. This may increase the potential for conflict and human rights abuses. Indeed, Hafner-Burton (2005) does not find evidence that economic integration (measured by total trade as a percentage of GDP) has a significant impact on repression, but finds that in export-led countries, the probability of repression rises with high levels of export flows.

Internal and external conflict, ethnic tension, law and order, and democratic 
accountability of governments are among the indicators that are of the most significance for the activities of multinational corporations (Busse and Hefeker 2007). If countries become involved in an unanticipated war, the probability of receiving foreign direct investment decreases, as does the magnitude of such investments (Li 2006). Hence, human rights abuses should decrease with a country's level of economic globalization. Since economic globalization brings advantages for governments that participate in economic integration (Dreher 2006a), regimes have an incentive to respect human rights. There are theoretical arguments as well as empirical evidence that suggest trade or economic globalization reduce conflict in a country, because "the possible loss of trade reduces the willingness ... to fight” (Morrow 1999: 481; see also Li and Sacko 2002; Iqbal and Zorn 2006).

Von Hayek (1960) argued that free trade and capital flows would lead to economic development, fostering the demand for democracy. Eichengreen and Leblang (2008) provide evidence for a mutual positive relationship between trade and democracy (an exception being labor-scarce countries). ${ }^{9}$ In line with hypothesis (i) of Poe and Tate's model, this is another argument for economic globalization improving human rights practices. These considerations lead to our first hypothesis:

\section{Hypothesis 1: Economic globalization improves a country's human rights practice.}

The success of companies operating globally is dependent on aspects like reputation, which means that these companies also have an incentive to uphold international human rights and basic labor standards if non-commitment is likely to become globally transparent. As the social integration aspect of globalization proceeds-for instance via the internet and other global communication media-the likelihood of human rights violations being discovered increases, and the negative effect of being caught magnifies. The skill revolution makes it easy to follow news about violations, however distant they may be (Rosenau 2003). Moreover, due to an increasing worldwide network of NGOs and other private groups (which is one aspect of social integration), the pressure on

\footnotetext{
${ }^{9}$ For recent work on this topic see also Iqbal and Zorn (2006).
} 
human rights violating regimes also rises. ${ }^{10}$ Hence, Rosenau (2003) points to the increased ease of mobilizing human rights supporters as a consequence of social globalization. Resistance against human rights violations can form more easily compared to a world where news spread less quickly. ${ }^{11}$ As one part of social globalization, international groups and networks are formed with the explicit goal of opposing repressive regimes. Successful concepts can then easily be identified and copied. ${ }^{12}$

Social globalization can generate massive international pressure on a government or enterprise. Hence, social globalization produces internationally recognized social norms that give governments, politicians, and managers an incentive to follow (Akerlof 1980; Bernheim 1994). If a country is highly dependent on tourism, social globalization offers a chance to attract tourists, but at the same time it incorporates the risk of losing them due to the negative publicity of human rights abuses. Overall, the increased visibility from social globalization can make governments all over the world feel more obliged to publicly react to such violations. Thus, social globalization should function as an incentive device against human rights abuses by increasing the ramifications of such abuses. Moreover, Rosenau (2003) argues that another channel of social globalization is the direct effect of immigration (and tourism) on the potential acceptance of different lifestyles, be it the acceptance of different religions, ethnicity, gender or sexual preferences. This reduces the potential for conflict and human rights abuses.

Hafner-Burton (2008), however, provides evidence that repressive governments criticized by NGOs, news media and international organizations, often strategically reduce particular forms of violations by offsetting this improvement with increased violations in other areas. As Rosenau (2003) points out, the skill revolution enables perpetrators, as well as victims, to respond to mobilizing powers: "It is worth recalling

\footnotetext{
${ }^{10}$ One example for this is Nike, which has had numerous "issues" where it was claimed by various NGOs that they were exploiting workers and using child labor in production. In 2001, Nike responded by providing a "corporate responsibility report," in which it admitted that child labor was used and promised to stop this practice (Boggan 2001).

${ }^{11}$ As one example, Rosenau (2003) points to NATO’s intervention in Kosovo, where media coverage arguably played a role.

${ }^{12}$ Rosenau (2003) proposes the example of land acquisition by the Inuit in Canada, which has been facilitated by the adaptation of successful concepts from other parts of the world.
} 
that a major consequence of the skill revolution is the growing capacity of people everywhere to know when, where, and how to engage in collective action, a capacity that can be just as easily put to the service of opposing as supporting what are regarded as human rights violations” (322-323). ${ }^{13}$ Migration flows lead to negative reactions by native citizens, in some countries giving rise to the success of right-wing parties and repressive policies. Still, on balance, we expect the positive effects of social globalization to dominate. We thus test the hypothesis:

\section{Hypothesis 2: Social globalization improves a country's human rights practice.}

Compliance with social norms originates from several sources-due to metanorms, dominance, internalization, deterrence, social proof, membership, law, or reputation (Axelrod 1986). Neighbor states and the international community could punish human rights abuses, though this sword proved to be rather blunt in cases such as the Darfur conflict. Membership in particular international organizations provides advantages that member countries do not want to jeopardize by allowing human rights abuses to occur. This leads us to the third dimension of globalization-political globalization.

The European integration process via the European Union (EU) is an example of the positive role political integration can play in encouraging human rights. Potential new members will only be affiliated, and win the substantial benefits of membership, if they fulfill a number of preconditions. For instance, members have to sign the European Convention for the Protection of Human Rights and Fundamental Freedoms, ${ }^{14}$ as well as other standards. Human rights abuses are prosecuted by the European Court of Human Rights. The sanctions imposed by the UN Security Council and other supra-national organizations to punish human rights violations are further instances where political globalization might, at least to a small extent, affect human rights. Regarding prosecution

\footnotetext{
${ }^{13}$ Rosenau (2003) points to the example of General Pinochet's custody in the United Kingdom, where Chilean crowds demonstrated both in favor and against his detention.

${ }^{14}$ The states of South- and Middle-America have also developed an American Convention of Human Rights.
} 
of genocide, war crimes and crimes against humanity, the UN established the International Criminal Court (ICC); for Ex-Yugoslavia and Ruanda there were extra courts established to punish the culprits. Hence, political integration should improve a government's respect for human rights.

An opposing view, first expressed by Chomsky and Herman (1979), and still being discussed today, argues that the amount of human rights violations would rise with the degree of economic association with power blocks like the United States or the European Union (Mitchell and McCormick 1988). According to this line of argument, developed economies further their own interests, for example through reforms at the World Trade Organization (WTO) or regional trade unions like the NAFTA (Stiglitz 2006). The formation of international organizations such as the WTO, NAFTA and the European Union, improve these nations' ability to build beneficial asymmetric global trade relations and other forms of power policy. As world markets are increasingly controlled by these power blocks, investment conditions are altered to the disadvantage of poorer nations, with persistent unemployment rising as a result (Stiglitz 2006). This power policy may prolong the impoverishment of countries in a stage of transition or backwardness (Stiglitz 2006). Following Poe and Tate (1994), this would impair human rights practices.

Though both arguments appear to be correct in practice, ${ }^{15}$ we assume that, on average, political globalization improves human rights practices:

\section{Hypothesis 3: Political globalization improves human rights practice.}

Thus, overall, we expect all three dimensions of globalization to improve governments' respect for human rights (on average). We next turn to the impact of economic freedom on human rights.

\subsection{Economic Freedom and Human Rights Abuses}

Economic freedom refers to the internal liberalization of economic rights, such as the "freedom to engage in economic transactions, without government interference but with

${ }^{15}$ Stiglitz (2006) discusses both arguments in a broader context. 
government support of the institutions necessary for that freedom, including rule of law, sound money, and open markets” (Deardorff's Glossary of International Economics ${ }^{16}$ ). Economic freedom is therefore the "degree to which a market economy is in place, where the central components are voluntary exchange, free competition, and protection of persons and property” (Berggren 2003: 193; see also Gwartney and Lawson 2002) and a limited degree of interventionism in the form of government ownership, regulations, and taxes. ${ }^{17}$ There is clear evidence that economic freedom fosters growth-enhancing incentives (Berggren 2003; de Haan and Sturm 2003). Economic freedom promotes high returns on productive efforts, and it enables individuals to allocate their talent and capital where it generates the highest value (Murphy et al. 1991). It is a precondition for (economic) globalization because it promotes foreign capital investment and the flow of trade towards preference satisfaction and highest return. Based on hypothesis (ii) of Poe and Tate's model, economic freedom should reduce human rights abuses.

As outlined above, a particular number of freedoms characterize democracies. Hence, there is a direct link to the literature on economic freedom and democracy (e.g., de Haan and Sturm 2003): While economic freedom promotes free markets, political freedom promotes democracy, so that both types of freedom are part of the same story. If economic freedom is significantly correlated with democracy, then hypothesis (i) of Poe and Tate's model suggests that an indirect nexus exists between economic freedom and regard for human rights via its common link to democracy. ${ }^{18}$

However, when looking back at the industrial revolution in Europe, we find a potentially negative effect of economic freedom on human rights. Entrepreneurs more or less had the right to treat their laborers in whichever way they saw fit. Political and economic leaders' interests went hand in hand, and economic freedom was exclusively developed towards the advantage of citizens owning property. As large parts of society were poor, exploitation and further impoverishment of complete swathes of land

\footnotetext{
${ }^{16}$ http://www-personal.umich.edu/ alandear/glossary/e.html (September 6, 2010).

${ }^{17}$ Economic freedom differs from political freedom (equal participation in political process, competition for political power, free and fair elections) and civil freedom (protection against unreasonable visitation, access to fair trials, freedom of assembly, freedom of religion, freedom of speech) (Berggren 2003: 194).

${ }^{18}$ Burkhart (2002) assumes a similar (indirect) effect of capitalism and human rights through democracy.
} 
occurred. Laborers had to work under degrading conditions, child labor was widespread, and laborers were disenfranchised (Marx 2002). ${ }^{19}$

Today, in the countries where the industrial revolution originated, economic freedom is still comparably high, but Europe is nevertheless well known for a markedly good human rights record. Marx's (1950) hypothesis that private property and a capitalistic system inevitably lead to disaster has not been proven to be true, arguably because the countries developed social security systems and labor protection standards, and the like, which reduced economic freedom but ensured greater respect for human rights. However, globalization might now spread a system of (pure) capitalism all over the world, so Marx's suspicion concerning economic freedom is indeed topical again. We thus test the following hypothesis:

\section{Hypothesis 4: Economic freedom improves a country's human rights practice.}

In the following we outline our measures of human rights and globalization, and confront our hypotheses with data.

\section{Measuring Human Rights}

Our definition of citizens' human rights follows Cingranelli and Richards (1999). Their Human Rights Dataset (CIRI, Cingranelli and Richards 2006) was specifically designed to allow for the testing of theories about causes and consequences of human rights violations and is widely used to do so. ${ }^{20}$ It provides quantitative information on governments' respect for various internationally recognized human rights, on an annual basis and for almost all countries around the world. ${ }^{21}$

\footnotetext{
${ }^{19}$ For example, Marx (2002: 239-240) cites a Justice of the Peace in Nottingham, who labels the working conditions in England in 1860 as 'slavery in social, bodily, ethically and mental respect'.

${ }^{20}$ See, e.g., Richards (1999), Abouharb and Cingranelli (2006, 2009), Goodlifee and Hawkins (2006), United Nations (2006), Blume and Voigt (2007), or Dreher et al. (2010).

${ }^{21}$ Note that we therefore do not investigate human rights violations from non-governmental actors. See Ferguson and Mansbach (2004) for a discussion.
} 
The CIRI measure draws from two sources, the U.S. Department of State's Country Reports on Human Rights Practices, and from Amnesty International's (AI) Annual Reports. Both offer detailed descriptions of human rights practices for most countries in the world. They are analyzed by country experts who code the human rights situation in a particular country and year on an ordinal scale. Each country is evaluated by at least two trained experts, following a very detailed set of instructions. ${ }^{22}$ Note that Cingranelli and Richards focus on actual human rights-related actions of governments, including all government agencies, such as police and military. In particular, the CIRI data refer to extrajudicial killings, people who have disappeared for political reasons, torture, political imprisonment, freedom of speech, freedom of religion, freedom of movement, political participation, and worker's rights. Each variable is coded on an ordinal scale, ranging between 0-2 and, depending on the variable considered, 0-4, where higher values reflect a better rating in the respective human rights dimension. ${ }^{23}$

In this paper we focus on two composite indicators provided by Cingranelli and Richards (1999) and Richards et al. (2001). The first composite index refers to physical integrity rights, which measures the absence of torture, extrajudicial killings, political imprisonments, and disappearance, on a scale of $0-8$. The second composite refers to empowerment rights and comprises the freedom of movement, freedom of speech, workers' rights, political participation, and freedom of religion, ranging from $0-10 .^{24}$

\footnotetext{
${ }^{22}$ The detailed coding rules are fixed in a coding manual and available from the CIRI Human Rights Data Project (http://ciri.binghamton.edu/documentation.asp, accessed April 15, 2008).

${ }^{23}$ The scoring of the ordinal indices rests on events-based criteria. While the exact description of how the individual dimensions are coded is not reproduced here due to space restraints, consider political or extrajudicial killings as an example. "Practically frequent” killings are coded as "zero," when more than 50 people have been killed in a particular year and country. "Practices occasionally" is coded as "one" when between 1-49 people have been killed, while a value of "two" is assigned when no killing occurred. As Cingranelli and Richards (1999) and Richards et al. (2001) show employing Mokken Scale Analysis, the government's decision to violate the individual rights is unidimensional. They can thus be aggregated to overall indices.

${ }^{24}$ The correlation between the physical integrity index and the empowerment index is 0.51 . Thus, the two indicators seem to be covering different aspects of human rights.
} 
Higher values represent better human rights practices. Appendix B gives a more detailed description of these components. ${ }^{25}$

\section{Figure 1: Development of physical integrity over time}

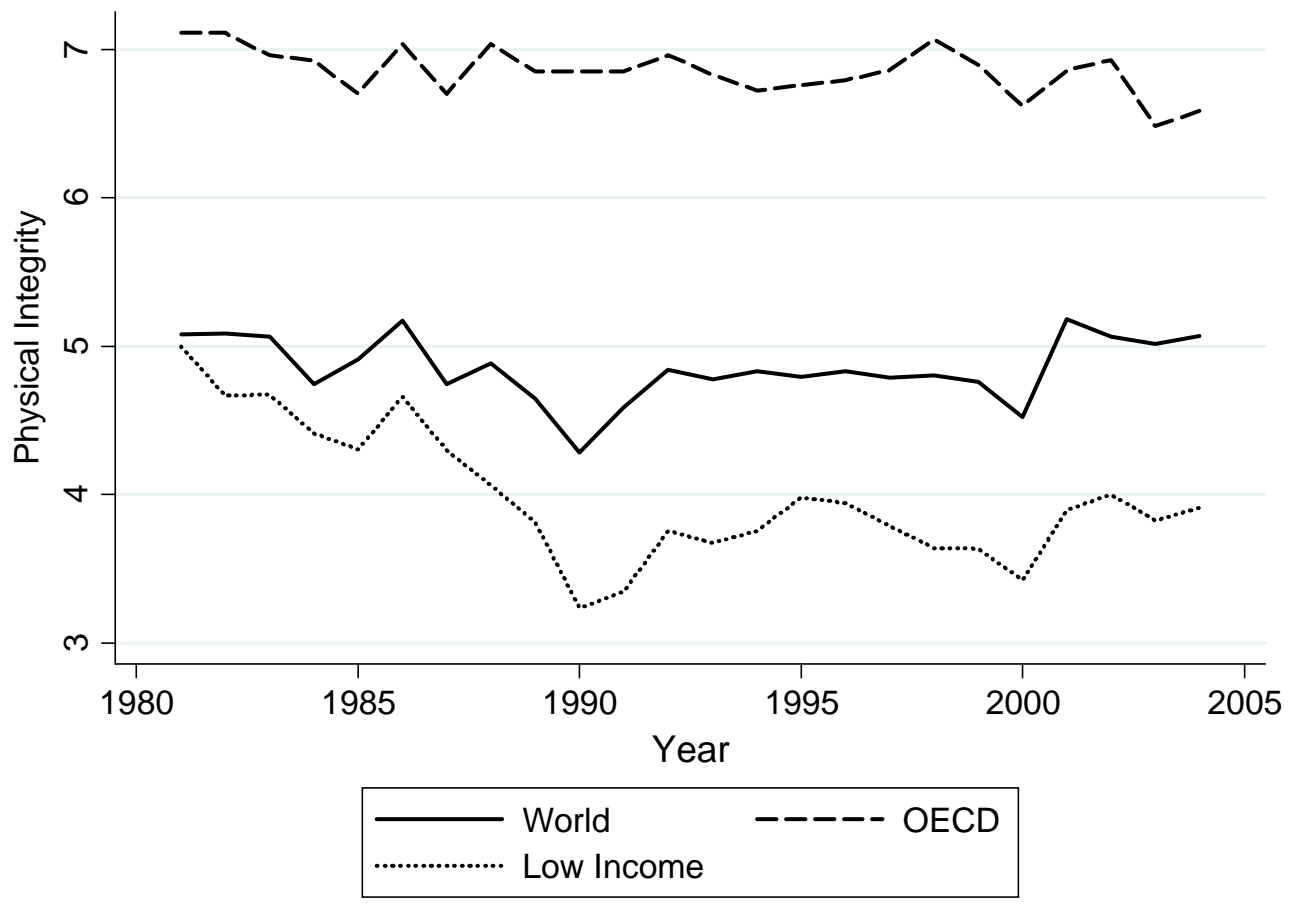

The upper line in Figure 1 shows the time path of the unweighted average of the physical integrity index for OECD countries over the 1981-2004 period. The lower line represents the average for low income countries, ${ }^{26}$ while the unweighted world average is shown in the middle. The number of countries covered rises from 125 in 1981, to 179 in 2004. The figure shows that the mean of the world index was fairly constant over time at a value of around 5. However, a substantial drop did occur around 1990. The average for the OECD countries is also rather constant over time, but at a higher level of around 7. Figure 1 shows that there is some variation in physical integrity for developing countries, with a substantial negative trend. The level of physical integrity peaked at 5 in 1981, fell to a

\footnotetext{
${ }^{25}$ Hafner-Burton and Ron (2009) discuss the limitations of the CIRI data in measuring human rights.

${ }^{26}$ Countries with low income are those with a 2004 GNI per capita of a maximum of \$US 825, according to the World Bank (2009) definition.
} 
low point of 3.2 in 1990, rose to 4 in 1995, and after declining again until 2000, was slightly below 4 in 2004.

\section{Figure 2: Development of empowerment rights over time}

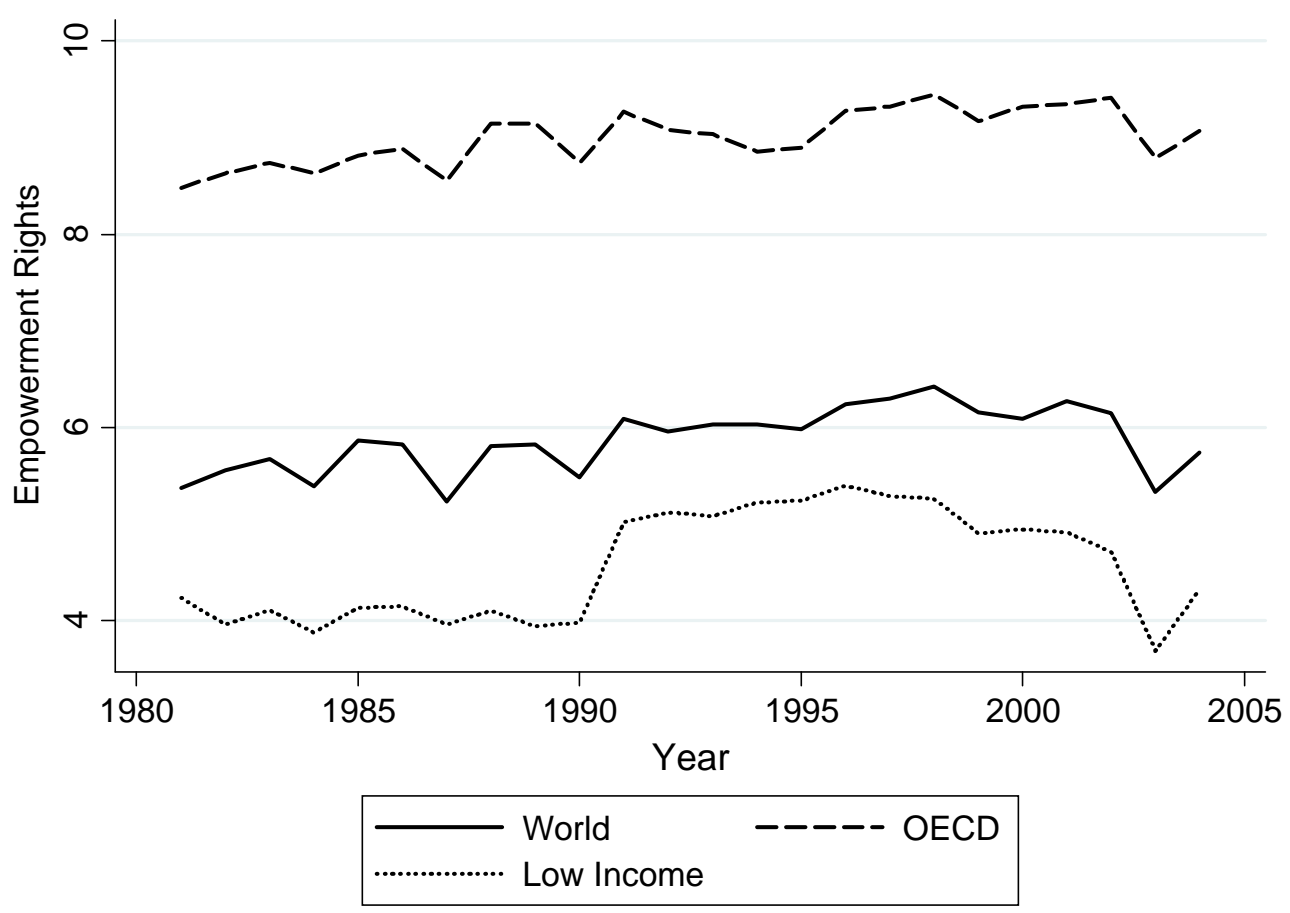

Figure 2 shows the development of empowerment rights. As can be seen, the average level of empowerment rose steadily over the period of observation (except in 2003), with similar developments in developing and OECD countries. The most substantial increase in empowerment was experienced in 1990, particularly in low income countries. ${ }^{27}$ The index mean is 4.6 for low income countries, more than 9 in OECD countries, and 5.9 for the world sample. Since 1996 we observe a negative trend in low-income countries, which started to reverse at the end of the sample period. The world sample contains 130 countries in 1981 and 181 in 2004.

\footnotetext{
${ }^{27}$ The apparent increase in low income countries from 1990 to 1991 is mainly driven by Mali, The Democratic Republic of Congo and Togo (increases of 4, 5 and 9 points, respectively). The decline in 2003 is mainly driven by Bangladesh, the Central African Republic, India, and Cambodia (all of which decreased by 5 points).
} 


\section{Measures of Economic Freedom and Globalization}

The measure of globalization that we employ is the KOF Index of Globalization developed in Dreher (2006a). ${ }^{28}$ It is based on 24 variables that relate to different dimensions of globalization. These dimensions are combined into three sub-indiceseconomic, political and social globalization — and one overall index of globalization.

More specifically, economic globalization is defined to have two dimensions. First, actual economic flows are taken to be measures of globalization. Second, as the economic literature usually employs proxies for restrictions on trade and capital, a second index captures this dimension. The sub-index on actual economic flows includes data on trade, flows and stocks of FDI, and portfolio investment. While these variables are straight-forward measures of globalization, income payments to foreign nationals and capital are also included to proxy for the extent to which a country employs foreign people and capital in its production processes.

The second sub-index refers to restrictions on trade and capital flows, using hidden import barriers, mean tariff rates, taxes on international trade and an index of capital controls. Given a certain level of trade, a country with higher revenues from tariffs is less globalized. To proxy restrictions on the capital account, an index constructed by Gwartney and Lawson (2002) is employed. Mean tariff rates are obtained from various sources. Gwartney and Lawson allocate a rating of 10 to countries that do not impose any tariffs. As the mean tariff rate increases, countries are assigned lower ratings. The rating declines toward zero as the mean tariff rate approaches 50 percent (a threshold not generally exceeded by most countries in their sample).

The KOF index classifies social globalization in three categories. ${ }^{29}$ The first covers personal contacts, the second includes data on information flows and the third measures cultural proximity. The personal contacts index is intended to capture the direct interaction among people living in different countries. It includes international telecom traffic (outgoing traffic in minutes per subscriber), international letters sent and received,

\footnotetext{
${ }^{28}$ We use the 2009 version of this index as documented in Dreher et al. (2008) which is available at http://globalization.kof.ethz.ch/.

${ }^{29}$ Similar proxies for globalization are used elsewhere (e.g., Iqbal and Zorn 2006). See Dreher et al. (2008) for a survey.
} 
and the degree of tourism (incoming and outgoing) a country's population is exposed to. Government and workers' transfers received and paid (as a percentage of GDP) measure whether, and to what extent, countries interact, while the stock of foreign population is included to capture existing interactions with people from other countries. The number of international letters sent and received measure direct interaction among people living in different countries.

While personal contact data are meant to capture measurable interactions among people from different countries, the sub-index on information flows is meant to measure the potential flow of ideas and images. It includes the number of internet users, cable television subscribers, number of radios and daily newspapers traded. To some extent, all these variables proxy people's potential for receiving news from other countries - they thus contribute to the global spread of ideas and events.

Cultural proximity is arguably the dimension of globalization which is most difficult to grasp. According to Saich (2000), cultural globalization in large part refers to the domination of U.S. cultural products. Arguably, the United States is the trendsetter in much of the global socio-cultural realm (Rosendorf 2000). As proxy for cultural proximity, the number of McDonald's restaurants located in a country is included. For many people, the global spread of McDonald's is synonymous with globalization itself. However, the number of IKEA (per capita) located in a country is also included. Imported and exported books (relative to GDP) are used to proxy the extent to which beliefs and values move across national borders.

To proxy the degree of political globalization, the number of embassies and high commissions in a country, the number of international organizations in which the country is a member, the number of international treaties ratified, and the number of UN peace missions a country participated in are used.

In constructing the indices of globalization, each of the variables is transformed to an index on a scale of one to one hundred, where one hundred is the maximum value for a specific variable and one is the minimum value. Higher values denote greater globalization. The data are transformed according to the percentiles of the original distribution. The weights for calculating the sub-indices are determined using principal components analysis for the entire sample of countries and years. 
Appendix A1 reports the individual components. As can be seen, economic, political and social integration carry roughly equal weights. The index is widely used as proxy for globalization in the recent literature. ${ }^{30}$

Turning to our measure of economic freedom, we employ the index provided by the Fraser Institute (Gwartney and Lawson 2008). The data is available in five yearintervals over the period 1970-2000, and on a yearly basis thereafter. It covers five broad categories of market-oriented policies and institutions: Size of Government (Area 1), Legal Structure and Security of Property Rights (Area 2), Access to Sound Money (Area 3), Exchange with Foreigners (Area 4), and Regulation of Credit, Labor and Business (Area 5). Each index ranges from 0-10, with 10 indicating the highest level of economic freedom. Appendix A2 contains the individual sub-components. As an alternative, we employ a second standard measure of economic freedom, that being the index developed by the Heritage Foundation and the Wall Street Journal (see Miller and Holmes 2009). Their Index of Economic Freedom is measured on a scale of 0 to 100 and is calculated as the mean of ten sub-components, which are measured on the same scale. The areas covered are Business, Trade, Money, Government, Fiscal Policy, Property Rights, Investment, Financial Freedom, Corruption, and Labor, where higher values indicate an economic environment or set of policies more conducive to economic freedom. Appendix A3 shows the individual components with their definitions.

\section{Data and Method}

We estimate pooled time-series cross-section (panel data) regressions. The yearly data extend to a maximum of 106 countries and cover the 1981-2004 period. Since some of the data are not available for all countries or years, the panel data are unbalanced and the number of observations depends on the choice of explanatory variables.

To test our hypotheses we estimate equations of the following form:

$$
\text { RIGHTS }_{i t}=\alpha_{1} \text { RIGHTS }_{i, t-1}+\alpha_{2} Z_{i, t}+\mu_{t}+u_{i t},
$$

where RIGHTS $_{i t}$ represents our measure of human rights in country $i$ at year $t$, and $Z$ is a vector containing the variables testing for our hypotheses, as introduced below.

\footnotetext{
${ }^{30}$ See http://globalization.kof.ethz.ch/papers/ for an extensive list of articles using the index.
} 
Finally, $\mu_{t}$ are time fixed effects and $u_{i t}$ is a well behaved error term. Note that we also include the lagged dependent variable, as human rights develop only slowly over time. Following the previous literature, we estimate our model employing ordered probit, with standard errors clustered at the country level. As a consequence, we cannot control for fixed country effects, as the resulting estimates would be biased due to the incidental parameter problem.

Before turning to the specific variables employed to test our hypotheses, we have to set up a baseline specification. As discussed above, the model of Poe and Tate (1994) gives guidance to what the core determinants of human rights are. Besides these, however, there is little consensus on what the additional determinants are, if any. Hence, we face the challenge of coming up with a robust empirical model. We tackle this problem by employing (variants of) the extreme bounds analysis (EBA), as proposed by Leamer (1983) and Levine and Renelt (1992). EBA enables us to examine whether the proposed variables are indeed robust determinants of human rights, independent of which additional variables are also included in the set of control variables.

To conduct an EBA, equations of the following general form are estimated:

$$
\text { RIGHTS }=\beta_{M} M+\beta_{F} F+\beta_{Z} Z+v,
$$

where RIGHTS is the measure of human rights, $M$ is a vector of "commonly accepted" explanatory variables and $F$ is a vector containing the variables of interest. The vector $Z$ contains up to three possible additional explanatory variables (as in Levine and Renelt 1992), which, according to the broader literature, are related to the dependent variable. The error term is $v$. The EBA-test for a variable in $F$ states that if the lower extreme bound for $\beta_{F}$-i.e., the lowest value for $\beta_{F}$ minus two standard deviations - is negative, while the upper extreme bound for $\beta_{F}$-i.e., the highest value for $\beta_{F}$ plus two standard deviations-is positive, the variable $F$ is not robustly related to RIGHTS.

Sala-i-Martin (1997) argues that this criterion is far too strong for any variable to pass. If the distribution of the parameter of interest has both positive and negative support, then a researcher is bound to find at least one regression model for which the estimated coefficient changes sign if enough regressions are run. Consequently, in what follows, not only do we report the extreme bounds, but also the percentage of the 
regressions in which the coefficient of the variable $F$ is statistically different from zero at the five percent level.

Moreover, instead of analyzing only the extreme bounds of the estimates of the coefficient for a particular variable, we follow Sala-i-Martin's (1997) recommended procedure and analyze the entire distribution. Accordingly, we also report the unweighted parameter estimate of $\beta_{F}$ and its standard error, as well as the unweighted cumulative distribution function, $\operatorname{CDF}(0)$. The latter represents the proportion of the cumulative distribution function lying on each side of zero. $\operatorname{CDF}(0)$ indicates the larger of the areas under the density function either above or below zero. So $\operatorname{CDF}(0)$ always lies between 0.5 and 1.0. However, in contrast to Sala-i-Martin, we use the unweighted, instead of the weighted, $\operatorname{CDF}(0){ }^{31}$

As we follow Poe and Tate (1994), our $M$ vector consists of the following variables: A proxy for democracy (Polity IV), population size, GDP per capita, a set of dummy variables controlling for legal origin, plus a dummy variable indicating the presence of a civil and/or international war (and the lagged dependent variable).

As detailed in section 2, we have collected a total of 52 variables potentially influencing the level of human rights to test competing theoretical and empirical findings. All variables and their sources are listed in Appendix B. After evaluating the robustness of the baseline specification, including these variables in all possible combinations of up to three, each of these variables is included in the base vector singularly (i.e., represents the variable in the $F$ vector), while the remaining 51 variables are used in the $Z$ vector. Thus, the first part of the analysis evaluates whether the variables in the base model are robustly related to human rights practice. The second part shows whether additional

\footnotetext{
${ }^{31}$ Sala-i-Martin (1997) proposes using the integrated likelihood to construct a weighted CDF(0). However, missing observations for some of the variables pose a problem. Sturm and de Haan (2002) show that the goodness-of-fit measure may not be a good indicator of the probability that a model is the true model and that the weights constructed in this way are not invariant to linear transformations of the dependent variable. Hence, changing scales could result in different outcomes and conclusions. We therefore employ the unweighted version. Furthermore, due to our unbalanced panel setup, we are unable to use the extension of the EBA called Bayesian Averaging of Classical Estimates (BACE) as introduced by Sala-i-Martin et al.
} (2004). 
variables should be among the explanatory variables when testing for the impact of globalization and economic freedom on human rights practice. ${ }^{32}$

The next section reports the results for the EBA; results for our specific hypotheses follow below.

\section{Findings}

\subsection{EBA Results}

The results for the EBA baseline models are presented in Table 1, while results for the additional variables are presented in Appendix C. In order to take account of the twosided nature of the test, we follow Sturm and de Haan's (2005) proposal to use a CDF(0) value of 0.95 as a threshold for which variables we consider to be robust. The upper panel of Table 1 shows the results for physical integrity rights, while the lower panel reports those for empowerment rights. As can be seen from both panels, the lagged dependent variable is clearly a robust determinant of current levels, with both $\operatorname{CDF}(0)$ s being equal to one. The results also show that all additional variables included in the baseline model are robust determinants of physical integrity rights. In line with Poe and Tate, less populous and more democratic countries have higher levels of human rights. Protection of physical integrity rights is also more pronounced in wealthier countries, measured by per capita GDP. Wars robustly reduce governments' respect for physical integrity rights.

In terms of legal origin, the four dummies are also robust determinants of physical integrity rights. When calculating F-tests for their joint significance, the average p-value amounts to 0.02 , indicating the joint significance of the legal origin dummies. We find that relative to Scandinavian legal origin (the omitted benchmark category) all other country groups show less respect for physical integrity rights.

While the results imply that the baseline variables chosen for the M-vector on theoretical grounds are well matched to the data for physical integrity rights, the lower part of Table 1 shows that this holds to a lesser extent for empowerment rights. All coefficients are of the same sign as for physical integrity rights. However, only democracy exceeds the threshold of a $\operatorname{CDF}(0)$ of 0.95 and can therefore be considered as

\footnotetext{
${ }^{32}$ Note that multicollinearity is not a major concern. Out of the 1771 pairwise correlations of the variables in the EBA, only 8 show a correlation of greater than 0.8 .
} 
a robust determinant of empowerment rights. Population, per capita GDP, and war experiences are no robust determinants of empowerment rights. The legal origin dummies are, at least individually, also not robust. Note, however, that the average p-value for their joint significance is 0.08 , indicating the joint significance of these dummies.

The results reported in appendix $\mathrm{C}$ show that the bulk of the remaining 52 control variables are not robust predictors of human rights. In fact, regarding physical integrity rights, none of the 52 variables passes the strict threshold of 0.95 . Six variables pass the lower threshold of a CDF(0) of 0.90 suggested by Sala-i-Martin (1997), however. All of them have the expected signs. Older democracies and states with a longer history of independence show greater respect for human rights. More FDI inflows, as proxy for one area of globalization, are associated with less human rights violations, as are the years the chief executive is in office and the number of government tiers. The latter two results imply that political stability and checks and balances promote human rights. In line with theory, human rights violations are more frequent in former Iberian colonies.

With respect to empowerment rights, the share of Protestants turns out to be a robust determinant according to the stricter threshold. As described in section 2, Protestants seem to be more tolerant and thus show greater respect for human rights. Four additional variables come close to our threshold: Population growth, the number of human rights NGOs, the share of the dominant religion and the dummy for left-wing governments. Population growth and a high share of a dominant religion seem to be detrimental to human rights practice, while human rights organizations and left-wing governments seem to be associated with less human rights violations. The latter finding might seem at odds with Poe and Tate (1994), but our dummy of left-wing governments typically refers to (social) democrats rather than socialists.

When testing our specific hypotheses below, we include all variables with a $\mathrm{CDF}(0)$ exceeding 0.95 to avoid the possibility of omitted variable bias. We tested for the robustness of our results, including those variables exceeding the lower threshold of 0.90 as well. $^{33}$

\footnotetext{
${ }^{33}$ All our results reported in Tables 2 and 3 remain qualitatively unchanged. The additional results are available on request.
} 


\subsection{Hypotheses Tests}

Table 2 shows the results for physical integrity rights, based on more than 2000 observations. Note that a potentially non-linear effect of GDP per capita could not be tested in the EBA framework, as in a non-linear model such as ordered probit a simple ttest on the squared term is meaningless (Ai and Norton 2003). One way of testing for the statistical significance of the squared GDP per capita term is via a likelihood-ratio test (Greene 2010). However, this cannot be done in a meaningful way in the EBA. We therefore present two sets of results here: One with, and one without the squared term. For all models, likelihood-ratio tests provide evidence for a better fit when including the squared term at the one percent level of significance. For the non-linear models, we also report the turning point in terms of GDP per capita (PPP adjusted). As reported at the bottom of the table, the turning point fluctuates between US\$2800-4800.

Turning to our variables of interest, we start by including one dimension of integration at a time and then include them jointly. Column 1-9 report the results excluding GDP per capita squared, while columns 10-18 include the squared term. According to column 1, governments' respect for physical integrity rights increases with economic integration, at the one percent level of significance. This is line with Hypothesis 1 . The same holds true when we substitute economic globalization for social globalization (in column 2) or political globalization (column 3). Therefore, Hypotheses 2 and 3 are also supported by the data. Column 4 includes the overall KOF Index of Globalization instead, which is significant at the one percent level, with a positive coefficient, as expected.

With respect to economic freedom, we find evidence for Hypothesis 4. Column 5 includes the Fraser index. The result shows that, at the five percent level of significance, governments' respect for physical integrity rights increases with greater freedom. Note however, that the number of observations is reduced to 611 , due to missing data on economic freedom for many years. Column 6 therefore includes the same index, but linearly interpolates the data in the years with missing observations. The result confirms the previous finding, at the one percent level of significance. ${ }^{34}$ When using the index

\footnotetext{
${ }^{34}$ When interpolating the data, we have to correct the standard errors to account for this. We do so by bootstrapping the standard errors with 1000 repetitions.
} 
provided by Heritage as an alternative (column 7), the coefficient is marginally insignificant.

As argued above, not accounting for all dimensions of integration might lead to an omitted variable bias. Therefore, we include all three indices of globalization jointly with the (interpolated) Fraser index. As can be seen, economic globalization is no longer significant at conventional levels, which might be due to multicollinearity. When we enter the KOF Index of Globalization jointly with the Fraser index, both are significant at the one percent level.

The results are very similar when squared per capita GDP is also included. The exception is that economic freedom measured by the Heritage index is now significant at the ten percent level (in column 16), and that social globalization becomes marginally insignificant when included jointly with the two other dimensions of globalization and the Fraser index.

Interestingly, the political dimension of globalization seems to dominate the economic and social dimensions. If this were true, human rights policy should concentrate on pushing political integration. However, we do not know whether the economic and social dimensions are really irrelevant to human rights, or whether multicollinearity exists among the individual dimensions, which does not allow us to identify their effect. Overall, we conclude that the data support our hypotheses well, even if some ambiguity regarding the relevance of the economic and social dimensions remains.

Table 3 replicates the analysis focusing on empowerment rights. In line with the results for the EBA above, population and per capita GDP are not significant at conventional levels in most specifications (when GDP per capita squared is excluded). The same holds for war experiences and the dummies for legal origin. The dummies are, however, jointly significant at the five percent level in all specifications, except those shown in columns 7 and 16 . Note that according to the likelihood-ratio test, the model including GDP per capita squared again fits the data better. The implied turning point is similar to the one above, between US\$ 3100-6000.

The results show that social globalization seems to be the only dimension of globalization which is robustly related to empowerment rights. The overall index of 
globalization is significant at the five percent level when GDP per capita squared is excluded (in column 5), but not significant at conventional levels with its inclusion (columns 13 and 18). To some extent, this could be explained by the fact that, in contrast to physical integrity rights, empowerment rights are not guaranteed to the same degree by international treaties (Hafner-Burton and Ron 2009). There is no clear consensus in the global community as to how these rights are exactly defined. Hence, the effect of liberal policies is likely to be more heterogeneous on empowerment, as compared to physical integrity rights, which makes it difficult to find statistically significant effects. Due to a lack of consensus, even the Western democracies prefer to focus on the more important physical integrity rights, neglecting fuzzy empowerment rights at the political stage. For similar reasons, economic integration may not bear a significant effect.

With respect to economic freedom, the Fraser index is significant at the five percent level throughout, with a positive coefficient, while the Heritage index is not. Overall, the data thus support hypotheses 2 and 4, but not 1 and 3 concerning empowerment rights.

Our next step is to test for the robustness of our main results. We therefore replicate the EBA reported above including our measures of globalization and economic freedom. However, to reduce clutter, we do not report the results in tables. With respect to physical integrity, we focus on column 18 in Table 2 and include all additional variables in all possible combinations, as above. According to the results, the KOF Index of Globalization and the Fraser index are clearly robust determinants of physical integrity rights, with the $\mathrm{CDF}(0)$ being greater than 0.95 for both variables. Regarding empowerment rights, we focus on column 17 (of Table 3) given that the overall KOF index was not significant at conventional levels in column 18 in the first place. Our results show that neither globalization nor economic freedom are robust determinants of empowerment rights. ${ }^{35}$ Therefore, as outlined above, the incentives to respect human rights due to globalization and economic freedom are too weak to affect empowerment rights. The lack of consensus over what is the appropriate level of empowerment rights might lead the "global community" at the social and political level into believing that complaining about a lack of empowerment rights in other countries, when compared to

\footnotetext{
${ }^{35}$ Note that the $\operatorname{CDF}(0)$ for both variables is even below 0.90 .
} 
their own rights at home, represents an inadequate outside interference in national issues: While physical integrity rights involve violations of basic human rights which are considered as inacceptable, empowerment rights involve markedly less strong human rights violations, and thus might be more acceptable to international observers.

Finally, we address the question whether causality indeed runs from globalization and economic freedom to human rights practice. Arguably, greater human rights might also lead to more liberalization. Table 4 runs Granger causality tests to address the issue. Causality, as defined by Granger (1969), implies that a variable $x$ is Granger-causing a variable $y$ if past values of $x$ help to explain $y$, once the past influence of $y$ has been accounted for.

If we have $\mathrm{N}$ cross-sectional units observed over $\mathrm{T}$ time periods, the model is:

$$
y_{i t}=\sum_{j=1}^{m} \alpha_{j} y_{i t-j}+\sum_{j=1}^{m} \beta_{j} x_{i t-j}+\varepsilon_{i t}
$$

where $i=1, \ldots, \mathrm{N}$ and $t=1, \ldots, \mathrm{T}$. The parameters are denoted $\alpha_{j}$ and $\beta_{j}$, the maximal lag length is $m$, while $\varepsilon_{i t}$ represents the disturbance. According to our data, a lag length of two is appropriate. Moreover, we use a fixed effects panel estimator with clustered standard errors when the dependent variable is globalization or economic freedom, and the ordered probit estimator with clustered standard errors for human rights. To test whether $x$ Granger-causes $y$ in equation (3), we run an F-test on the $\beta_{j}$. We report the corresponding p-values in Table 4. Note that the null hypothesis of this test is that $x$ does not Granger-cause $y$. The table reads as follows: The first entry of a p-value of 0.00 indicates that economic globalization Granger-causes physical integrity. The next entry in the same row (0.45) signals that physical integrity does not Granger-cause economic globalization (as we fail to reject $\mathrm{H}_{0}$ ). Regarding physical integrity, we see that Granger causality only runs from globalization and economic freedom to human rights.

The picture is less distinct when it comes to empowerment rights. Despite the fact that, again, all globalization measures Granger-cause empowerment, there are also instances where the reverse is true. However, remember that we only found significant results for social globalization and the Fraser index in Table 3. Those two measures are not Granger-caused by empowerment rights. 
To get a feeling for the magnitude of the estimated effects, we calculate the marginal effects at the mean of all significant variables and report them in Table 5. Note, however, that in the ordered probit model the marginal effects are not straightforward to interpret. We therefore calculate the estimated probabilities before and after a shock of one standard deviation on all of our physical integrity rights variables of interest. This is reported in Figure 1. According to the figure, the social component of globalization and the KOF Index of Globalization seem to have the largest impact on physical integrity. The estimated probability of observing the values of 3 and 4 are (at the means of all variables) $6.1 \%$ and $19.1 \%$, respectively, while values 6 and 7 occur with a predicted probability of $26.6 \%$ and $14.9 \%$. After an increase in the KOF Index of Globalization by one standard deviation, these predictions get substantially lower for low values, namely $3.1 \%$ and $13.5 \%$ for values 3 and 4 , while they increase for the high values 6 and 7 to $30.8 \%$ and $21.0 \%$, respectively. We conclude that these effects are not only statistically significant, but also quantitatively important.

How does this compare to the other covariates for physical integrity rights? A shock of one standard deviation in the (log) population size increases the probability of observing a human rights value of 4 by $5.0 \%$, while it decreases the probability of observing the value of 7 by $5.6 \%$. An increase in democracy by one standard deviation decreases (increases) the probability of observing an index value of 4 (7) by $4.4 \%$ (4.9\%). Relative to Scandinavian legal origin, other countries have a probability of observing an index value of 4 which is between $12 \%$ to $17 \%$ higher, while the chance of observing a value of 7 is lower by $12 \%$ to $22 \%$. Finally, a civil and/or international war increases the likelihood of lower human rights by $6.7 \%$ and decreases the probability of high human rights by $6.9 \%$. As compared to the other variables that can be directly influenced by policy, population size and level of democracy, the influence of internal and external economic liberalization is at least as large, if not larger.

\section{Conclusion}

This paper extends the model of Poe and Tate (1994) to include economic freedom and three dimensions of globalization. We use the KOF Index of Globalization and two indices of economic freedom to empirically analyze whether globalization and 
liberalization affect human rights practice in a panel of 106 countries over the 1981-2004 period. We extend the literature in three important ways: (i) we provide the first comprehensive analysis of the effects of economic globalization on human rights practice that includes all dimensions of economic globalization; (ii) we additionally investigate the specific effects of social and political globalization; and (iii) at the same time, we analyze the effects of economic freedom on human rights. Investigating all these issues with the same data allows a comprehensive insight into the link between liberal policies and respect for human rights. While the main control variables have been derived based on theoretical considerations from the previous literature, we also provide extensive robustness tests using more than 50 additional variables in an Extreme Bounds Analysis.

Our results show that physical integrity rights significantly increase with economic freedom as well as political, social, and economic globalization (when we include these variables separately). When we include them together, we find that only economic freedom and political globalization remain significant. However, we do not know whether this is due to multicollinearity or rather the actual irrelevance of the insignificant dimensions. ${ }^{36}$ In any case, the overall KOF Index of Globalization turns out to be a highly robust determinant of physical integrity rights, as is economic freedom.

These results are important extensions to the model of Poe and Tate (1994). Consider the case of Croatia. Physical integrity increased from 2 in 1995 to 7 in 1996. While the levels of democracy, population, and GDP per capita remained more or less constant, the KOF Index of Globalization increased by 7 points (i.e., 15 percent) and the economic freedom index by roughly 10 percent. One year later physical integrity reached its maximum value of 8 as both globalization and economic freedom continued to grow. Similar examples are Morocco 1990-1991, South Africa 1994-1995, and Kenya 19921993, among many others. As the increase in physical integrity rights cannot be explained by the model of Poe and Tate alone, adding our variables of main interest adds explanatory power.

\footnotetext{
${ }^{36}$ Our result regarding economic globalization is in line with Hafner-Burton (2005). Hafner-Burton uses a more traditional measure of globalization-trade-and does not find a significant effect of economic globalization on human rights.
} 
Interestingly, we do not find similarly robust effects of economic freedom and globalization on empowerment rights. While we find that empowerment rights rise with social globalization and economic freedom, these results are not robust to the choice of control variables, as indicated by the Extreme Bounds Analysis.

Overall, we conclude that the hypothesized incentives to respect human rights provided by globalization mainly work for narrow basic human rights ("physical integrity rights”), but not for the broader “empowerment rights.” This may be the case because (i) there is a lack of international consensus about what precisely comprises these empowerment rights and (ii) given that these are "weaker" human rights, violations are more readily accepted by international observers. The combination of lack of consensus and lower importance may therefore cause empowerment rights violations to be considered as internal national affairs. 


\section{References}

Abouharb, M. Rodwan, and David L. Cingranelli. 2006. The human rights effects of World Bank structural adjustment lending, 1981-2000. International Studies Quarterly 50 (2): 233-62.

Abouharb, M. Rodwan, and David L. Cingranelli. 2009. IMF programs and human rights, 1981-2003. Review of International Organizations 4 (1): 47-72.

Ai, Chunrong, and Edward C. Norton. 2003. Interaction terms in logit and probit models. Economics Letters 80 (1): 123-29.

Akerlof, George A. 1980. A theory of social custom, of which unemployment may be one consequence. Quarterly Journal of Economics 94 (4): 749-75.

Alesina, Alberto, William Easterly, Arnaud Devleeschauwer, Sergio Kurlat, and Romain Wacziarg. 2003. Fractionalization. Journal of Economic Growth 8 (2): 155-94.

Amnesty International. 2006. Amnesty International Report 2006. London: Amnesty International. http://web.amnesty.org/report2006/index-eng (accessed January 10, 2007).

Apodaca, Claire. 2001. Global economic patterns and personal integrity rights after the Cold War. International Studies Quarterly 45 (4): 587-602.

Arruñada, Benito. 2010. Protestants and Catholics: Similar work ethic, different social ethic. Economic Journal 120 (547): 890-918.

Axelrod, Robert. 1986. An evolutionary approach to norms. American Political Science Review 80 (4): 1095-111.

Barro, Robert J., and Jong-Wha Lee. 2000. International data on educational attainment: Updates and implications. CID Working Paper No. 42.

Beck, Thorsten, George Clarke, Alberto Groff, Philip Keefer, and Patrick Walsh. 2001. New tools in comparative political economy: The database of political institutions. World Bank Economic Review 15 (1): 165-76.

Berggren, Niclas. 2003. The benefits of economic freedom. A survey. The Independent Review 8 (2): 193-211.

Bernheim, B. Douglas. 1994. A theory of conformity. Journal of Political Economy 102 (5): 841-77. 
Bjørnskov, Christian. 2006. Globalization and economic freedom: New evidence using the Dreher indices. mimeo.

Blume, Lorenz, and Stefan Voigt. 2007. The economic effects of human rights. Kyklos 60 (4): 509-38.

Boggan, Steve. 2001. Nike admits to mistakes over child labor. The Independent, October 20.

Boockmann, Bernhard, and Axel Dreher. 2003. The contribution of the IMF and the World Bank to economic freedom. European Journal of Political Economy 19 (3): 633-49.

Burkhart, Ross E. 2002. The Capitalist Political Economy and Human Rights: CrossNational Evidence. Social Science Journal 39, 2: 155-70.

Busse, Matthias, and Carsten Hefeker. 2007. Political risk, institutions and foreign direct investment. European Journal of Political Economy 23 (2): 397-415.

Cheibub, José Antonio, Jennifer Gandhi, and James Raymond Vreeland. 2010. Democracy and dictatorship revisited. Public Choice 143 (1-2): 67-101.

Chomsky, Noam, and Edward S. Herman. 1979. The political economy of human rights: The Washington connection and third world fascism. Boston: South End Press.

CEPII. 2010. Distances database. http://www.cepii.fr/anglaisgraph/bdd/distances.htm (accessed April 10, 2010).

Cingranelli, David L., and David L. Richards. 1999. Measuring the level, pattern, and sequence of government respect for physical integrity rights. International Studies Quarterly 43 (2): 407-18.

Cingranelli, David L., and David L. Richards. 2006. The Cingranelli-Richards (CIRI) human rights dataset 2006. http://www.humanrightsdata.org/ (accessed September 27, 2006).

Davenport, Christian. 1996. The weight of the past: Exploring lagged determinants of political repression. Political Research Quarterly 49 (2): 377-403.

Davenport, Christian, and David A. Armstrong II. 2004. Democracy and the violation of human rights: A statistical analysis from 1976 to 1996. American Journal of Political Science 48 (3): 538-54. 
De Haan, Jakob, and Jan-Egbert Sturm. 2003. Does more democracy lead to greater economic freedom? New evidence for developing countries. European Journal of Political Economy 19 (3): 547-63.

Dreher, Axel. 2006a. Does globalization affect growth? Evidence from a new index of globalization. Applied Economics 38 (10): 1091-110.

Dreher, Axel. 2006b. IMF and economic growth: The effects of programs, loans, and compliance with conditionality. World Development 34 (5): 769-88.

Dreher, Axel, Martin Gassebner, and Lars-H. Siemers. 2010. Does terror threaten human rights? Evidence from panel data. Journal of Law and Economics 53, (1): 65-93.

Dreher, Axel, Noel Gaston, and Pim Martens. 2008. measuring globalisation - gauging its consequences. New York: Springer.

Dreher, Axel, and Roland Vaubel. 2009. Foreign exchange intervention and the political business cycle: A panel data analysis. Journal of International Money and Finance 28 (5): 755-75.

Easterly, William, and Mirvat Sewadeh. 2001. Global development network growth database. World Bank, Economic and Development Research Group.

Eichengreen, Barry, and David Leblang. 2008. Democracy and globalization, Economics and Politics 20 (3): 289-334.

Evans, Tony. 1999. Trading human rights. In Global trade and global social issues, edited by A. Taylor and C. Thomas, 31-52. London et al.: Routledge.

Ferguson, Yale H., and Richard W. Mansbach. 2004. Remapping global politics history's revenge and future shock. Cambridge: Cambridge University Press.

Gallup, John L., Andrew D. Mellinger, and Jeffrey D. Sachs. 2001. Geography datasets. http://www.cid.harvard.edu/ (accessed September 12, 2006).

Gelleny, Ronal D., and Matthew McCoy. 2001. Globalization and government policy independence: The issue of taxation. Political Research Quarterly 54 (3): 509-29.

Gleditsch, Nils. P., Peter Wallensteen, Mikael Eriksson, Margareta Sollenberg, and Håvard Strand. 2002. Armed conflict 1946-2001: A new dataset. Journal of Peace Research 39 (5): 615-37.

Goodlifee, Jay, and Darren G. Hawkins. 2006. Explaining commitment: States and the convention against torture. Journal of Politics 68 (2): 358-71. 
Granger, Clive W.J. 1969. Testing for causality and feedback. Econometrica 37 (3): 42438.

Greene, W. 2010. Testing hypotheses about interaction terms in nonlinear models. Economics Letters 107 (2): 291-96.

Gurr, Ted Robert. 1986. Persisting patterns of repression and rebellion: Foundations for a general theory of political coercion. In Persistent patterns and emergent structures in a waning century, edited by M. Karns, 149-68. New York: Praeger.

Gwartney, James G., and Robert A. Lawson. 2002. Economic freedom of the world: 2002 annual report. Vancouver: Fraser Institute.

Gwartney, James G., and Robert A. Lawson. 2008. Economic freedom of the world: 2008 annual report. Vancouver: Fraser Institute.

Hafner-Burton, Emilie M. 2005. Right or robust? The sensitive nature of repression to globalization. Journal of Peace Research 42 (6): 679-98.

Hafner-Burton, Emilie M. 2008. Sticks and stones: Naming and shaming the human rights enforcement problem. International Organization 62 (4): 689-716.

Hafner-Burton, Emilie M., and James Ron. 2009. Seeing double - human rights impact through qualitative and quantitative eyes. World Politics 61 (2): 360-401.

Henderson, Conway W. 1991. Conditions affecting the use of political repression. Journal of Conflict Resolution 35 (1): 120-42.

Huntington, Samuel. 1968. Political order in changing societies. New Haven: Yale University Press.

Inglehart, Ronald. 1988. The renaissance of political culture. American Political Science Review 82 (4): 1203-230.

Iqbal, Zaryab, and Christopher Zorn. 2006. The two faces of globalization. mimeo.

Kuznets, Simon. 1955. Economic growth and income inequality. American Economic Review 45 (1): 1-28.

La Porta, Rafael, Florencio Lopez-de-Silanes, and Andrei Shleifer. 2008. The economic consequences of legal origins. Journal of Economic Literature 46 (2): 285-332.

Leamer, Edward E. 1983. Let's take the con out of econometrics. American Economic Review 73 (1): 31-43. 
Levine, Ross, and David Renelt. 1992. A sensitivity analysis of cross-county growth regressions. American Economic Review 82 (4): 942-63.

$\mathrm{Li}$, Quan. 2006. Political violence and foreign direct investment. In Research in global strategic management, Vol. 12, Regional Economic Integration, edited by M. Fratianni and A.M. Rugman, 231-55. Oxford: Elsevier.

Li, Quan, and David Sacko. 2002. The (ir)relevance of militarized interstate disputes for international trade. International Studies Quarterly 46 (1): 11-43.

Marshall, Monty G., and Keith Jaggers. 2000. Polity IV project: Political regime characteristics and transitions, 1800-2000. http://www.cidcm.umd.edu/inscr/polity/ (accessed September 15, 2006).

Marx, Karl. 1950[1844]. Nationalökonomie und Philosophie. Cologne and Berlin: Verlag Gustav Kiepenheuer.

Marx, Karl. 2002[1872, $2^{\text {nd }}$ ed.]. Das Kapital, $3^{\text {rd }}$ ed. Cologne: Parkland Verlag.

Miller, Terry, and Kim R. Holmes. 2009. Index of economic freedom. The link between economic opportunity and prosperity. Washington, DC: Heritage Foundation.

Mitchell, Neil, and John McCormick. 1988. Economic and political explanations of human rights violations. World Politics 40 (4): 476-98.

Morrow, James D. 1999. How could trade affect conflict? Journal of Peace Research 36 (4): 481-89.

Murphy, Kevin M., Andrei Shleifer, and Robert W. Vishny. 1991. The allocation of talent: implications for growth. Quarterly Journal of Economics 106 (2): 503-30.

Norris, Pippa. 2009. Democracy time-series dataset. Release 3.0. http://www.hks.harvard.edu/fs/pnorris/Data/Data.htm (accessed July 01, 2010).

Persson, Thorsten, and Guido Tabellini. 2003. The economic effect of constitutions: What do the data say? Cambridge, MA: MIT Press.

Poe, Steven, and C. Neal Tate. 1994. Repression of human rights to personal integrity in the 1980s: A global analysis. American Political Science Review 88 (4): 853-72.

Pollis, Admantia. 2004. Human rights and globalization. Journal of Human Rights 3 (3): 343-58. 
Rabet, Delphine. 2009. Human rights and globalization: The myth of corporate social responsibility? Journal of Alternative Perspectives in the Social Sciences 1 (2): 463-75.

Richards, David L. 1999. Perilous proxy: Human rights and the presence of national elections. Social Science Quarterly 80 (4): 648-65.

Richards, David L., Ronald Gelleny, and David Sacko. 2001. Money with a mean streak? Foreign economic penetration and government respect for human rights in developing countries. International Studies Quarterly 45 (2): 219-39.

Rosenau, James N. 2003. Distant proximities: Dynamics beyond globalization. Princeton: Princeton University Press.

Rosendorf, Neal M. 2000. Social and cultural globalization: Concepts, history and America's role. In Governance in a globalizing world, edited by J.S. Nye and J.D. Donahue, 109-34. Washington, DC: Brookings Institution Press.

Sala-i-Martin, Xavier. 1997. I just ran two million regressions. American Economic Review 87 (2): 178-83.

Sala-i-Martin, Xavier, Gernot Doppelhofer, and Ronald I. Miller. 2004. Determinants of long-term growth: A Bayesian averaging of classical estimates (BACE) approach. American Economic Review 94 (4): 813-35.

Saich, Tony. 2000. Globalization, governance, and the authoritarian state: China. In Governance in a globalizing world, edited by J.S. Nye and J.D. Donahue, 208-28. Washington, DC: Brookings Institution Press.

Simmons, Beth, and Allison Danner. 2010. Credible commitments and the International Criminal Court. International Organization 64 (2): 225-56.

Stiglitz, Joseph E. 2006. Making globalization work. New York: W. W. Norton \& Company.

Sturm, Jan-Egbert, and Jakob de Haan. 2002. How robust is Sala-i-Martin's robustness analysis? mimeo.

Sturm, Jan-Egbert, and Jakob de Haan. 2005. Determinants of long-term growth: New results applying robust estimation and extreme bounds analysis. Empirical Economics 30 (3): 597-617.

Treisman, Daniel. 2000. Decentralization and the quality of government. mimeo. 
Union of International Associations. 2000. Yearbook of international organizations. Munich: Thomson.

United Nations. 2005. Human development report - international cooperation at a crossroads: Aid, trade and security in an unequal world. New York: United Nations Development Programme.

United Nations. 2006. Indicators for human rights-based approaches to development in UNDP programming. New York: United Nations Development Programme.

von Hayek, Friedrich August. 1960. The constitution of liberty. Chicago: University of Chicago Press.

World Bank. 2009. World development indicators, CD-Rom. Washington, D.C. 
Table 1: Results EBA - Baseline Variables, Ordered Probit

a) Physical Integrity Rights

\begin{tabular}{lcccccc}
\hline Variable & Avg. Beta & Avg.Std.E. & \%Sign. & CDF-U & lwr Bound & upr Bound \\
\hline Lagged dependent & 0.574 & 0.039 & 99.96 & 0.9999 & -1.076 & 1.672 \\
Population (log) & -0.158 & 0.039 & 98.47 & 0.9960 & -1.530 & 3.131 \\
GDP p.c. (log) & 0.239 & 0.082 & 86.16 & 0.9635 & -20.094 & 5.060 \\
Democracy & 0.033 & 0.011 & 96.30 & 0.9845 & -0.520 & 2.057 \\
War & -0.404 & 0.160 & 88.90 & 0.9635 & -4.542 & 3.725 \\
Legal origin British & -1.262 & 0.239 & 88.30 & 0.9536 & -15.034 & 2.120 \\
Legal origin French & -1.272 & 0.242 & 91.15 & 0.9779 & -13.544 & 2.442 \\
Legal origin Socialist & -1.014 & 0.255 & 90.41 & 0.9821 & -11.622 & 4.635 \\
Legal origin German & -1.126 & 0.241 & 85.79 & 0.9932 & -13.136 & 2.271 \\
\hline
\end{tabular}

b) Empowerment Rights

\begin{tabular}{lcccccc}
\hline Variable & Avg. Beta & Avg.Std.E. & \%Sign. & CDF-U lwr Bound upr Bound \\
\hline Lagged dependent & 0.576 & 0.044 & 100.00 & 1.0000 & -0.159 & 34.699 \\
Population (log) & -0.040 & 0.041 & 41.79 & 0.7693 & -2.179 & 9.091 \\
GDP p.c. (log) & 0.089 & 0.080 & 38.94 & 0.7499 & -32.623 & 4.357 \\
Democracy & 0.091 & 0.015 & 99.58 & 0.9992 & -0.802 & 12.221 \\
War & -0.173 & 0.158 & 32.71 & 0.8541 & -18.522 & 15.776 \\
Legal origin British & -0.830 & 0.322 & 77.52 & 0.9185 & -20.390 & 20.149 \\
Legal origin French & -0.610 & 0.318 & 57.79 & 0.9016 & -76.877 & 6.732 \\
Legal origin Socialist & -0.930 & 0.363 & 67.70 & 0.9410 & -88.412 & 10.638 \\
Legal origin German & -0.610 & 0.363 & 21.14 & 0.8803 & -64.582 & 10.068 \\
\hline
\end{tabular}

Note: Results based on 22,146 (physical integrity) and 22,085 (empowerment) regressions, respectively, including time-specific fixed effects. 'Avg. Beta' and 'Avg.Std.E.' report the unweighted average coefficient and standard error, respectively. '\%Sign.' refers to the percentage of regressions in which the respective variable is significant at least at the 5\% level. 'CDF-U' is the unweighted CDF as detailed in the text. The threshold to consider a variable robust is 0.95. 'lwr Bound' and 'upr Bound' give the lowest and highest value of point estimate minus/plus two standard deviations. 
Table 2 - Results Physical Integrity Rights, Ordered Probit

\begin{tabular}{|c|c|c|c|c|c|c|c|c|c|c|c|c|c|c|c|c|c|c|}
\hline \multirow{3}{*}{ Lagged dependent } & (1) & (2) & (3) & (4) & (5) & (6) & (7) & (8) & (9) & (10) & (11) & (12) & (13) & (14) & (15) & (16) & (17) & (18) \\
\hline & 0.565 & 0.561 & 0.560 & 0.552 & 0.535 & 0.551 & 0.539 & 0.545 & 0.541 & 0.537 & 0.535 & 0.530 & 0.525 & 0.498 & 0.522 & 0.506 & 0.520 & 0.513 \\
\hline & $(23.46) * * *$ & $(24.03)^{* * *}$ & $(23.46) * * *$ & $(23.93)^{* * *}$ & $(13.22)^{* * *}$ & $(29.49) * * *$ & $(12.74)^{* * *}$ & $(29.70) * * *$ & $(29.46)^{* * *}$ & $(21.31)^{* * *}$ & $(22.49) * * *$ & $(20.75) * * *$ & $(21.66) * * *$ & $(11.80)^{* * * *}$ & $(29.09)^{* * * *}$ & $(11.49)^{* * *}$ & $(26.52)^{* * *}$ & $(28.13)^{* * *}$ \\
\hline Population (log) & $\begin{array}{l}-0.107 \\
(4.59)^{* * *}\end{array}$ & $\begin{array}{l}-0.091 \\
(3.77)^{* * *}\end{array}$ & $\begin{array}{c}-0.176 \\
(6.91)^{* * *}\end{array}$ & $\begin{array}{c}-0.125 \\
(5.81)^{* * *}\end{array}$ & $\begin{array}{l}-0.150 \\
(5.00)^{* * *}\end{array}$ & $\begin{array}{c}-0.133 \\
(7.69)^{* * *}\end{array}$ & $\begin{array}{c}-0.165 \\
(5.18)^{* * *}\end{array}$ & $\begin{array}{l}-0.165 \\
(6.14)^{* * *}\end{array}$ & $\begin{array}{l}-0.130 \\
(7.55)^{* * *}\end{array}$ & $\begin{array}{c}-0.131 \\
(5.49)^{* * *}\end{array}$ & $\begin{array}{l}-0.117 \\
(4.66)^{* * *}\end{array}$ & $\begin{array}{c}-0.202 \\
(7.81)^{* * *}\end{array}$ & $\begin{array}{c}-0.148 \\
(6.85)^{* * *}\end{array}$ & $\begin{array}{c}-0.181 \\
(5.57)^{* * *}\end{array}$ & $\begin{array}{c}-0.156 \\
(9.02)^{* * *}\end{array}$ & $\begin{array}{c}-0.189 \\
(5.33)^{* * *}\end{array}$ & $\begin{array}{c}-0.196 \\
(7.20)^{* * *}\end{array}$ & $\begin{array}{l}-0.152 \\
(8.93)^{* * *}\end{array}$ \\
\hline GDP p.c. (log) & $\begin{array}{l}0.033 \\
(0.76)\end{array}$ & $\begin{array}{l}-0.039 \\
(0.73)\end{array}$ & $\begin{array}{c}0.100 \\
(2.99)^{* * *}\end{array}$ & $\begin{array}{l}-0.035 \\
(0.69)\end{array}$ & $\begin{array}{l}0.053 \\
(1.04)\end{array}$ & $\begin{array}{c}0.065 \\
(2.09)^{* *}\end{array}$ & $\begin{array}{c}0.125 \\
(2.08)^{* *}\end{array}$ & $\begin{array}{l}-0.081 \\
(1.82)^{*}\end{array}$ & $\begin{array}{l}-0.063 \\
(1.64)\end{array}$ & $\begin{array}{l}-2.441 \\
(5.50)^{* * *}\end{array}$ & $\begin{array}{c}-2.183 \\
(5.74)^{* * *}\end{array}$ & $\begin{array}{l}-2.257 \\
(6.10)^{* * *}\end{array}$ & $\begin{array}{c}-2.303 \\
(6.20)^{* * *}\end{array}$ & $\begin{array}{l}-2.774 \\
(5.19)^{* * *}\end{array}$ & $\begin{array}{c}-2.218 \\
(6.49)^{* * *}\end{array}$ & $\begin{array}{c}-2.757 \\
(4.58)^{* * *}\end{array}$ & $\begin{array}{c}-2.360 \\
(6.81)^{* * *}\end{array}$ & $\begin{array}{l}-2.308 \\
(6.72) * * *\end{array}$ \\
\hline GDP p.c. (log) squared & & & & & & & & & & $\begin{array}{c}0.150 \\
(5.46)^{* * *}\end{array}$ & $\begin{array}{c}0.130 \\
(5.59)^{* * *}\end{array}$ & $\begin{array}{c}0.142 \\
(6.23)^{* * *}\end{array}$ & $\begin{array}{c}0.137 \\
(6.11)^{* * *}\end{array}$ & $\begin{array}{c}0.170 \\
(5.28)^{* * *}\end{array}$ & $\begin{array}{c}0.138 \\
(6.76)^{* * *}\end{array}$ & $\begin{array}{c}0.171 \\
(4.75)^{* * *}\end{array}$ & $\begin{array}{c}0.140 \\
(6.69)^{* * *}\end{array}$ & $\begin{array}{c}0.136 \\
(6.66) * * *\end{array}$ \\
\hline Democracy & $\begin{array}{c}0.025 \\
(4.46)^{* * * *}\end{array}$ & $\begin{array}{c}0.023 \\
(4.28)^{* * *}\end{array}$ & $\begin{array}{c}0.024 \\
(4.51)^{* * * *}\end{array}$ & $\begin{array}{c}0.022 \\
(3.96)^{* * *}\end{array}$ & $\begin{array}{c}0.031 \\
(4.18)^{* * *}\end{array}$ & $\begin{array}{c}0.025 \\
(6.23)^{* * *}\end{array}$ & $\begin{array}{c}0.030 \\
(4.01)^{* * *}\end{array}$ & $\begin{array}{c}0.023 \\
(5.17)^{* * *}\end{array}$ & $\begin{array}{c}0.022 \\
(5.39)^{* * *}\end{array}$ & $\begin{array}{c}0.032 \\
(4.65)^{* * *}\end{array}$ & $\begin{array}{c}0.031 \\
(4.81)^{* * *}\end{array}$ & $\begin{array}{c}0.032 \\
(4.96)^{* * *}\end{array}$ & $\begin{array}{c}0.030 \\
(4.61)^{* * *}\end{array}$ & $\begin{array}{c}0.042 \\
(4.40)^{* * *}\end{array}$ & $\begin{array}{c}0.033 \\
(7.65)^{* * *}\end{array}$ & $\begin{array}{c}0.041 \\
(4.21)^{* * *}\end{array}$ & $\begin{array}{c}0.029 \\
(6.47)^{* * *}\end{array}$ & $\begin{array}{c}0.030 \\
(6.95)^{* * *}\end{array}$ \\
\hline War & $\begin{array}{c}-0.330 \\
(3.45)^{* * *}\end{array}$ & $\begin{array}{c}-0.362 \\
(3.86)^{* * *}\end{array}$ & $\begin{array}{c}-0.349 \\
(3.83)^{* * * *}\end{array}$ & $\begin{array}{c}-0.340 \\
(3.68)^{* * *}\end{array}$ & $\begin{array}{l}-0.504 \\
(2.82)^{* * *}\end{array}$ & $\begin{array}{c}-0.300 \\
(2.98)^{* * *}\end{array}$ & $\begin{array}{l}-0.354 \\
(2.39)^{* *}\end{array}$ & $\begin{array}{c}-0.329 \\
(3.41)^{* * *}\end{array}$ & $\begin{array}{c}-0.310 \\
(3.21)^{* * *}\end{array}$ & $\begin{array}{c}-0.389 \\
(4.04)^{* * *}\end{array}$ & $\begin{array}{c}-0.425 \\
(4.46)^{* * *}\end{array}$ & $\begin{array}{c}-0.418 \\
(4.60)^{* * *}\end{array}$ & $\begin{array}{c}-0.407 \\
(4.34)^{* * *}\end{array}$ & $\begin{array}{c}-0.595 \\
(3.24)^{* * *}\end{array}$ & $\begin{array}{c}-0.369 \\
(3.58)^{* * *}\end{array}$ & $\begin{array}{c}-0.499 \\
(3.52)^{* * *}\end{array}$ & $\begin{array}{c}-0.380 \\
(3.85)^{* * *}\end{array}$ & $\begin{array}{c}-0.378 \\
(3.78)^{* * * *}\end{array}$ \\
\hline Legal origin British & $\begin{array}{c}-1.367 \\
(7.11)^{* * *}\end{array}$ & $\begin{array}{l}-1.363 \\
(6.63)^{* * * *}\end{array}$ & $\begin{array}{l}-1.214 \\
(6.33)^{* * *}\end{array}$ & $\begin{array}{c}-1.269 \\
(6.27)^{* * *}\end{array}$ & $\begin{array}{l}-1.231 \\
(6.41)^{* * *}\end{array}$ & $\begin{array}{c}-1.422 \\
(5.09)^{* * *}\end{array}$ & $\begin{array}{c}-1.425 \\
(4.59)^{* * *}\end{array}$ & $\begin{array}{l}-1.267 \\
(3.23)^{* * *}\end{array}$ & $\begin{array}{c}-1.333 \\
(3.22)^{* * *}\end{array}$ & $\begin{array}{l}-1.160 \\
(6.04)^{* * * *}\end{array}$ & $\begin{array}{l}-1.194 \\
(6.00)^{* * *}\end{array}$ & $\begin{array}{l}-1.021 \\
(5.50)^{* * * *}\end{array}$ & $\begin{array}{c}-1.092 \\
(5.57)^{* * *}\end{array}$ & $\begin{array}{l}-0.990 \\
(4.32)^{* * *}\end{array}$ & $\begin{array}{c}-1.243 \\
(4.12)^{* * *}\end{array}$ & $\begin{array}{c}-1.229 \\
(4.06)^{* * *}\end{array}$ & $\begin{array}{c}-1.064 \\
(3.18)^{* * *}\end{array}$ & $\begin{array}{c}-1.159 \\
(4.12)^{* * *}\end{array}$ \\
\hline Legal origin French & $\begin{array}{c}-1.377 \\
(7.09)^{* * *}\end{array}$ & $\begin{array}{c}-1.373 \\
(6.53)^{* * *}\end{array}$ & $\begin{array}{c}-1.318 \\
(6.78)^{* * *}\end{array}$ & $\begin{array}{c}-1.301 \\
(6.27)^{* * *}\end{array}$ & $\begin{array}{c}-1.202 \\
(5.96)^{* * *}\end{array}$ & $\begin{array}{c}-1.446 \\
(5.15)^{* * *}\end{array}$ & $\begin{array}{c}-1.391 \\
(4.50)^{* * *}\end{array}$ & $\begin{array}{c}-1.285 \\
(3.29)^{* * *}\end{array}$ & $\begin{array}{c}-1.335 \\
(3.23)^{* * *}\end{array}$ & $\begin{array}{c}-1.091 \\
(5.67)^{* * *}\end{array}$ & $\begin{array}{l}-1.130 \\
(5.51)^{* * *}\end{array}$ & $\begin{array}{c}-1.041 \\
(5.52)^{* * *}\end{array}$ & $\begin{array}{c}-1.041 \\
(5.16)^{* * *}\end{array}$ & $\begin{array}{c}-0.870 \\
(3.76)^{* * *}\end{array}$ & $\begin{array}{c}-1.185 \\
(3.92)^{* * *}\end{array}$ & $\begin{array}{c}-1.080 \\
(3.59)^{* * *}\end{array}$ & $\begin{array}{c}-1.017 \\
(3.05)^{* * *}\end{array}$ & $\begin{array}{c}-1.078 \\
(3.82)^{* * *}\end{array}$ \\
\hline Legal origin Socialist & $\begin{array}{c}-1.213 \\
(5.99)^{* * *}\end{array}$ & $\begin{array}{c}-1.254 \\
(5.84)^{* * *}\end{array}$ & $\begin{array}{c}-1.124 \\
(5.23)^{* * *}\end{array}$ & $\begin{array}{c}-1.132 \\
(5.28)^{* * *}\end{array}$ & $\begin{array}{c}-1.115 \\
(4.93)^{* * *}\end{array}$ & $\begin{array}{c}-1.108 \\
(3.79)^{* * *}\end{array}$ & $\begin{array}{c}-1.218 \\
(3.85)^{* * *}\end{array}$ & $\begin{array}{c}-0.943 \\
(2.34)^{* *}\end{array}$ & $\begin{array}{c}-1.036 \\
(2.49)^{* *}\end{array}$ & $\begin{array}{c}-0.809 \\
(3.82)^{* * *}\end{array}$ & $\begin{array}{c}-0.893 \\
(4.11)^{* * *}\end{array}$ & $\begin{array}{c}-0.720 \\
(3.24)^{* * *}\end{array}$ & $\begin{array}{c}-0.754 \\
(3.46)^{* * *}\end{array}$ & $\begin{array}{l}-0.616 \\
(2.27)^{* *}\end{array}$ & $\begin{array}{c}-0.730 \\
(2.30)^{* *}\end{array}$ & $\begin{array}{c}-0.709 \\
(2.17)^{* *}\end{array}$ & $\begin{array}{l}-0.554 \\
(1.59)\end{array}$ & $\begin{array}{c}-0.663 \\
(2.23)^{* *}\end{array}$ \\
\hline Legal origin German & $\begin{array}{c}-1.016 \\
(3.98)^{* * * *}\end{array}$ & $\begin{array}{c}-1.078 \\
(3.80)^{* * *}\end{array}$ & $\begin{array}{c}-0.985 \\
(3.91)^{* * *}\end{array}$ & $\begin{array}{c}-0.949 \\
(3.42)^{* * *}\end{array}$ & $\begin{array}{c}-1.095 \\
(3.98)^{* * *}\end{array}$ & $\begin{array}{c}-1.177 \\
(3.99)^{* * *}\end{array}$ & $\begin{array}{c}-1.186 \\
(3.45)^{* * *}\end{array}$ & $\begin{array}{c}-0.996 \\
(2.46)^{* *}\end{array}$ & $\begin{array}{l}-1.022 \\
(2.37)^{* *}\end{array}$ & $\begin{array}{c}-0.955 \\
(4.26)^{* * *}\end{array}$ & $\begin{array}{c}-1.018 \\
(3.95)^{* * *}\end{array}$ & $\begin{array}{c}-0.910 \\
(3.97)^{* * *}\end{array}$ & $\begin{array}{c}-0.886 \\
(3.37)^{* * *}\end{array}$ & $\begin{array}{c}-1.020 \\
(3.71)^{* * *}\end{array}$ & $\begin{array}{c}-1.112 \\
(3.55)^{* * *}\end{array}$ & $\begin{array}{c}-1.172 \\
(3.69)^{* * *}\end{array}$ & $\begin{array}{c}-0.927 \\
(2.69)^{* * *}\end{array}$ & $\begin{array}{c}-0.958 \\
(3.14)^{* * *}\end{array}$ \\
\hline Economic globalization & $\begin{array}{c}0.010 \\
(3.37)^{* * *}\end{array}$ & & & & & & & $\begin{array}{c}3.2 \mathrm{E}-04 \\
(0.11)\end{array}$ & & $\begin{array}{c}0.009 \\
(3.36)^{* * *}\end{array}$ & & & & & & & $\begin{array}{l}0.001 \\
(0.28)\end{array}$ & \\
\hline Social globalization & & $\begin{array}{c}0.015 \\
(3.69)^{* * *}\end{array}$ & & & & & & $\begin{array}{c}0.008 \\
(2.25)^{* *}\end{array}$ & & & $\begin{array}{c}0.013 \\
(3.29)^{* * *}\end{array}$ & & & & & & $\begin{array}{l}0.005 \\
(1.31)\end{array}$ & \\
\hline Politicial globalization & & & $\begin{array}{c}0.007 \\
(3.22)^{* * *}\end{array}$ & & & & & $\begin{array}{c}0.008 \\
(3.63)^{* * *}\end{array}$ & & & & $\begin{array}{c}0.008 \\
(3.34)^{* * *}\end{array}$ & & & & & $\begin{array}{c}0.008 \\
(3.72)^{* * *}\end{array}$ & \\
\hline KOF globalization & & & & $\begin{array}{c}0.018 \\
(4.21)^{* * *}\end{array}$ & & & & & $\begin{array}{c}0.015 \\
(5.22)^{* * *}\end{array}$ & & & & $\begin{array}{c}0.018 \\
(4.36)^{* * *}\end{array}$ & & & & & $\begin{array}{c}0.015 \\
(4.91)^{* * *}\end{array}$ \\
\hline Fraser & & & & & $\begin{array}{c}0.153 \\
(2.50) * *\end{array}$ & & & & & & & & & $\begin{array}{c}0.153 \\
(2.39)^{* *}\end{array}$ & & & $\begin{array}{c}0.161 \\
(4.40)^{* * * *}\end{array}$ & $\begin{array}{c}0.125 \\
(3.84)^{* * *}\end{array}$ \\
\hline Fraser (interpolated) & & & & & & $\begin{array}{c}0.167 \\
(4.87)^{* * *}\end{array}$ & & $\begin{array}{c}0.158 \\
(4.43)^{* * *}\end{array}$ & $\begin{array}{c}0.125 \\
(3.66)^{* * *}\end{array}$ & & & & & & $\begin{array}{c}0.165 \\
(5.27)^{* * *}\end{array}$ & & & \\
\hline Heritage & & & & & & & $\begin{array}{l}0.009 \\
(1.49)\end{array}$ & & & & & & & & & $\begin{array}{c}0.012 \\
(1.88)^{*}\end{array}$ & & \\
\hline Obser & 2095 & 2136 & 2157 & 2157 & 611 & 2090 & 797 & 2027 & 2090 & 2095 & 2136 & 21 & 215 & 61 & 2090 & 797 & 2027 & 2090 \\
\hline Countries & 106 & 108 & 109 & 109 & 107 & 107 & 108 & 10 & 107 & 10 & 10 & 的 & 的 & 10 & 10 & 10 & 10 & \\
\hline R-sq & 0.31 & 0.31 & 0.30 & 0.30 & 0.30 & 0.30 & 0.30 & 0.31 & 0.31 & 0. & 0. & 0. & $0.3^{3}-x$ & 0. & 0. & 0.3 & 0. & 0. \\
\hline Turning point in $\$$ & & & & & & & & & & 3418 & 4430 & 2828 & 4470 & 3494 & 3091 & 3170 & 4576 & 4843 \\
\hline
\end{tabular}

Notes: All regressions include dummies for each year. The standard errors are clustered at the country level, except in columns 7 , 8 , $9,15,17,18$ where they were bootstrapped using 1000 replications. Turning point refers to the minimum of per capita GDP. The R-squared reported is a pseudo R-squared. */**/*** indicates significance at the 10/5/1-\% level. 
Table 3 - Results Empowerment Rights, Ordered Probit

\begin{tabular}{|c|c|c|c|c|c|c|c|c|c|c|c|c|c|c|c|c|c|c|}
\hline \multirow{3}{*}{ Lagged dependent } & (1) & (2) & (3) & (4) & (5) & (6) & (7) & (8) & (9) & (10) & (11) & (12) & (13) & (14) & (15) & (16) & (17) & (18) \\
\hline & 0.552 & 0.541 & 0.549 & 0.545 & 0.580 & 0.543 & 0.763 & 0.534 & 0.539 & 0.541 & 0.535 & 0.541 & 0.539 & 0.569 & 0.533 & 0.745 & 0.530 & 0.533 \\
\hline & $(14.76)^{* * *}$ & $(15.25)^{* * *}$ & $(15.21)^{* * *}$ & $(14.89)^{* * *}$ & $(10.30)^{* * *}$ & $(18.93)^{* * *}$ & $(12.72)^{* * *}$ & $(19.08)^{* * *}$ & $(19.47)^{* * *}$ & $(15.44)^{* * *}$ & $(15.73)^{* * *}$ & $(15.57)^{* * *}$ & $(15.48)^{* * *}$ & $(10.38)^{* * *}$ & $(19.17)^{* * *}$ & $(12.50)^{* * *}$ & $(18.64)^{* * *}$ & $(18.21)^{* * *}$ \\
\hline Population (log) & $\begin{array}{l}0.017 \\
(0.50)\end{array}$ & $\begin{array}{c}0.061 \\
(1.73)^{*}\end{array}$ & $\begin{array}{l}-0.018 \\
(0.47)\end{array}$ & $\begin{array}{l}0.020 \\
(0.59)\end{array}$ & $\begin{array}{l}0.023 \\
(0.52)\end{array}$ & $\begin{array}{l}0.017 \\
(0.71)\end{array}$ & $\begin{array}{l}0.010 \\
(0.24)\end{array}$ & $\begin{array}{l}0.034 \\
(0.98)\end{array}$ & $\begin{array}{l}0.022 \\
(0.89)\end{array}$ & $\begin{array}{l}-0.013 \\
(0.37)\end{array}$ & $\begin{array}{l}0.025 \\
(0.65)\end{array}$ & $\begin{array}{l}-0.019 \\
(0.50)\end{array}$ & $\begin{array}{l}-0.007 \\
(0.20)\end{array}$ & $\begin{array}{l}-0.003 \\
(0.08)\end{array}$ & $\begin{array}{l}-0.008 \\
(0.30)\end{array}$ & $\begin{array}{l}-0.007 \\
(0.16)\end{array}$ & $\begin{array}{l}0.016 \\
(0.45)\end{array}$ & $\begin{array}{l}-0.005 \\
(0.21)\end{array}$ \\
\hline GDP p.c. (log) & $\begin{array}{l}0.074 \\
(1.00)\end{array}$ & $\begin{array}{l}-0.112 \\
(1.26)\end{array}$ & $\begin{array}{l}0.081 \\
(1.60)\end{array}$ & $\begin{array}{l}-0.058 \\
(0.64)\end{array}$ & $\begin{array}{l}0.100 \\
(1.26)\end{array}$ & $\begin{array}{l}0.037 \\
(0.91)\end{array}$ & $\begin{array}{c}0.202 \\
(2.36)^{* *}\end{array}$ & $\begin{array}{l}-0.093 \\
(1.27)\end{array}$ & $\begin{array}{l}-0.069 \\
(1.04)\end{array}$ & $\begin{array}{c}-2.537 \\
(3.69)^{* * * *}\end{array}$ & $\begin{array}{c}-2.175 \\
(3.02)^{* * *}\end{array}$ & $\begin{array}{c}-2.485 \\
(3.65)^{* * *}\end{array}$ & $\begin{array}{c}-2.327 \\
(3.19)^{* * *}\end{array}$ & $\begin{array}{c}-2.700 \\
(3.34)^{* * *}\end{array}$ & $\begin{array}{c}-2.431 \\
(4.94)^{* * *}\end{array}$ & $\begin{array}{c}-2.896 \\
(3.19)^{* * *}\end{array}$ & $\begin{array}{c}-2.170 \\
(4.15)^{* * *}\end{array}$ & $\begin{array}{c}-2.359 \\
(4.65)^{* * *}\end{array}$ \\
\hline GDP p.c. (log) squared & & & & & & & & & & $\begin{array}{c}0.155 \\
(3.72)^{* * *}\end{array}$ & $\begin{array}{c}0.125 \\
(2.80)^{* * *}\end{array}$ & $\begin{array}{c}0.152 \\
(3.72)^{* * *}\end{array}$ & $\begin{array}{c}0.138 \\
(3.04)^{* * *}\end{array}$ & $\begin{array}{c}0.163 \\
(3.39)^{* * *}\end{array}$ & $\begin{array}{c}0.145 \\
(5.03)^{* * *}\end{array}$ & $\begin{array}{c}0.180 \\
(3.37)^{* * *}\end{array}$ & $\begin{array}{c}0.126 \\
(3.99)^{* * *}\end{array}$ & $\begin{array}{c}0.139 \\
(4.53)^{* * * *}\end{array}$ \\
\hline Democracy & $\begin{array}{c}0.077 \\
(6.26)^{* * *}\end{array}$ & $\begin{array}{c}0.079 \\
(6.92)^{* * *}\end{array}$ & $\begin{array}{c}0.076 \\
(6.30)^{* * *}\end{array}$ & $\begin{array}{c}0.079 \\
(6.60)^{* * *}\end{array}$ & $\begin{array}{c}0.066 \\
(3.25)^{* * *}\end{array}$ & $\begin{array}{c}0.081 \\
(7.60)^{* * *}\end{array}$ & $\begin{array}{c}0.091 \\
(3.45)^{* * *}\end{array}$ & $\begin{array}{c}0.082 \\
(7.87)^{* * *}\end{array}$ & $\begin{array}{c}0.083 \\
(7.99)^{* * *}\end{array}$ & $\begin{array}{c}0.086 \\
(6.89)^{* * *}\end{array}$ & $\begin{array}{c}0.086 \\
(7.16)^{* * *}\end{array}$ & $\begin{array}{c}0.086 \\
(6.83)^{* * * *}\end{array}$ & $\begin{array}{c}0.086 \\
(6.97)^{* * *}\end{array}$ & $\begin{array}{c}0.078 \\
(3.69) * * *\end{array}$ & $\begin{array}{c}0.090 \\
(8.77)^{* * *}\end{array}$ & $\begin{array}{c}0.105 \\
(3.52)^{* * *}\end{array}$ & $\begin{array}{c}0.089 \\
(8.15)^{* * *}\end{array}$ & $\begin{array}{c}0.090 \\
(8.71)^{* * * *}\end{array}$ \\
\hline War & $\begin{array}{l}-0.166 \\
(1.53)\end{array}$ & $\begin{array}{l}-0.183 \\
(1.58)\end{array}$ & $\begin{array}{l}-0.165 \\
(1.51)\end{array}$ & $\begin{array}{l}-0.156 \\
(1.42)\end{array}$ & $\begin{array}{l}-0.137 \\
(0.63)\end{array}$ & $\begin{array}{l}-0.088 \\
(0.83)\end{array}$ & $\begin{array}{l}-0.068 \\
(0.38)\end{array}$ & $\begin{array}{l}-0.117 \\
(1.03)\end{array}$ & $\begin{array}{l}-0.088 \\
(0.82)\end{array}$ & $\begin{array}{l}-0.157 \\
(1.40)\end{array}$ & $\begin{array}{l}-0.168 \\
(1.44)\end{array}$ & $\begin{array}{l}-0.157 \\
(1.41)\end{array}$ & $\begin{array}{l}-0.152 \\
(1.35)\end{array}$ & $\begin{array}{l}-0.079 \\
(0.35)\end{array}$ & $\begin{array}{l}-0.079 \\
(0.72)\end{array}$ & $\begin{array}{l}-0.044 \\
(0.22)\end{array}$ & $\begin{array}{l}-0.105 \\
(0.97)\end{array}$ & $\begin{array}{l}-0.079 \\
(0.71)\end{array}$ \\
\hline Legal origin British & $\begin{array}{l}0.056 \\
(0.12)\end{array}$ & $\begin{array}{l}0.057 \\
(0.14)\end{array}$ & $\begin{array}{l}0.222 \\
(0.50)\end{array}$ & $\begin{array}{l}0.087 \\
(0.21)\end{array}$ & $\begin{array}{l}-0.077 \\
(0.18)\end{array}$ & $\begin{array}{l}0.065 \\
(0.30)\end{array}$ & $\begin{array}{l}-0.212 \\
(0.60)\end{array}$ & $\begin{array}{l}0.171 \\
(0.71)\end{array}$ & $\begin{array}{l}0.070 \\
(0.32)\end{array}$ & $\begin{array}{l}0.338 \\
(0.68)\end{array}$ & $\begin{array}{l}0.276 \\
(0.60)\end{array}$ & $\begin{array}{l}0.364 \\
(0.75)\end{array}$ & $\begin{array}{l}0.316 \\
(0.67)\end{array}$ & $\begin{array}{l}0.163 \\
(0.36)\end{array}$ & $\begin{array}{l}0.300 \\
(1.32)\end{array}$ & $\begin{array}{l}0.065 \\
(0.18)\end{array}$ & $\begin{array}{l}0.326 \\
(1.35)\end{array}$ & $\begin{array}{l}0.293 \\
(1.32)\end{array}$ \\
\hline Legal origin French & $\begin{array}{l}0.426 \\
(0.90)\end{array}$ & $\begin{array}{l}0.498 \\
(1.11)\end{array}$ & $\begin{array}{l}0.559 \\
(1.19)\end{array}$ & $\begin{array}{l}0.474 \\
(1.06)\end{array}$ & $\begin{array}{l}0.090 \\
(0.19)\end{array}$ & $\begin{array}{c}0.465 \\
(1.90)^{*}\end{array}$ & $\begin{array}{l}0.295 \\
(0.75)\end{array}$ & $\begin{array}{c}0.611 \\
(2.39)^{* *}\end{array}$ & $\begin{array}{c}0.477 \\
(1.96)^{* *}\end{array}$ & $\begin{array}{c}0.898 \\
(1.67)^{*}\end{array}$ & $\begin{array}{c}0.851 \\
(1.67)^{*}\end{array}$ & $\begin{array}{c}0.915 \\
(1.72)^{*}\end{array}$ & $\begin{array}{c}0.867 \\
(1.66)^{*}\end{array}$ & $\begin{array}{l}0.525 \\
(0.98)\end{array}$ & $\begin{array}{c}0.884 \\
(3.43)^{* * *}\end{array}$ & $\begin{array}{c}0.823 \\
(1.75)^{*}\end{array}$ & $\begin{array}{c}0.921 \\
(3.36)^{* * *}\end{array}$ & $\begin{array}{c}0.872 \\
(3.38)^{* * * *}\end{array}$ \\
\hline Legal origin Socialist & $\begin{array}{l}-0.071 \\
(0.15)\end{array}$ & $\begin{array}{l}-0.064 \\
(0.14)\end{array}$ & $\begin{array}{l}0.053 \\
(0.11)\end{array}$ & $\begin{array}{l}-0.020 \\
(0.04)\end{array}$ & $\begin{array}{l}-0.038 \\
(0.08)\end{array}$ & $\begin{array}{l}0.118 \\
(0.45)\end{array}$ & $\begin{array}{l}-0.561 \\
(1.36)\end{array}$ & $\begin{array}{c}0.162 \\
(0.59)\end{array}$ & $\begin{array}{l}0.105 \\
(0.41)\end{array}$ & $\begin{array}{l}0.437 \\
(0.84)\end{array}$ & $\begin{array}{l}0.344 \\
(0.69)\end{array}$ & $\begin{array}{l}0.451 \\
(0.87)\end{array}$ & $\begin{array}{l}0.406 \\
(0.80)\end{array}$ & $\begin{array}{l}0.419 \\
(0.79)\end{array}$ & $\begin{array}{c}0.568 \\
(2.04)^{* *}\end{array}$ & $\begin{array}{l}-0.019 \\
(0.04)\end{array}$ & $\begin{array}{c}0.529 \\
(1.86)^{*}\end{array}$ & $\begin{array}{c}0.548 \\
(1.98)^{* *}\end{array}$ \\
\hline Legal origin German & $\begin{array}{l}0.320 \\
(0.69)\end{array}$ & $\begin{array}{l}0.337 \\
(0.73)\end{array}$ & $\begin{array}{l}0.435 \\
(0.96)\end{array}$ & $\begin{array}{l}0.385 \\
(0.85)\end{array}$ & $\begin{array}{l}-0.132 \\
(0.29)\end{array}$ & $\begin{array}{l}0.281 \\
(1.07)\end{array}$ & $\begin{array}{l}-0.280 \\
(0.57)\end{array}$ & $\begin{array}{l}0.353 \\
(1.26)\end{array}$ & $\begin{array}{l}0.334 \\
(1.23)\end{array}$ & $\begin{array}{l}0.524 \\
(1.03)\end{array}$ & $\begin{array}{l}0.499 \\
(0.97)\end{array}$ & $\begin{array}{l}0.543 \\
(1.08)\end{array}$ & $\begin{array}{l}0.536 \\
(1.05)\end{array}$ & $\begin{array}{l}0.041 \\
(0.08)\end{array}$ & $\begin{array}{c}0.473 \\
(1.68)^{*}\end{array}$ & $\begin{array}{l}-0.088 \\
(0.17)\end{array}$ & $\begin{array}{l}0.465 \\
(1.58)\end{array}$ & $\begin{array}{c}0.480 \\
(1.76)^{*}\end{array}$ \\
\hline Protestant share & $\begin{array}{c}0.013 \\
(3.47)^{* * * *}\end{array}$ & $\begin{array}{c}0.013 \\
(3.77)^{* * *}\end{array}$ & $\begin{array}{c}0.013 \\
(3.86)^{* * *}\end{array}$ & $\begin{array}{c}0.012 \\
(3.65)^{* * *}\end{array}$ & $\begin{array}{c}0.009 \\
(1.88 * *\end{array}$ & $\begin{array}{c}0.013 \\
(5.52)^{* * *}\end{array}$ & $\begin{array}{c}0.019 \\
(5.16) * * *\end{array}$ & $\begin{array}{c}0.014 \\
(5.96)^{* * *}\end{array}$ & $\begin{array}{c}0.012 \\
(5.37)^{* * * *}\end{array}$ & $\begin{array}{c}0.014 \\
(3.90) * * *\end{array}$ & $\begin{array}{c}0.014 \\
(3.95)^{* * *}\end{array}$ & $\begin{array}{c}0.014 \\
(3.97)^{* * *}\end{array}$ & $\begin{array}{c}0.014 \\
(3.91)^{* * * *}\end{array}$ & $\begin{array}{c}0.010 \\
(2.05)^{* *}\end{array}$ & $\begin{array}{c}0.014 \\
(6.06 * * *\end{array}$ & $\begin{array}{c}0.021 \\
(4.88)^{* * * *}\end{array}$ & $\begin{array}{c}0.015 \\
(6.16)^{* * * *}\end{array}$ & $\begin{array}{c}0.014 \\
(5.73)^{* * *}\end{array}$ \\
\hline Economic globalization & $\begin{array}{c}0.003 \\
(0.76)\end{array}$ & & & & & & & $\begin{array}{r}-0.006 \\
(1.61)\end{array}$ & & $\begin{array}{l}0.001 \\
(0.14)\end{array}$ & & & & & & & $\begin{array}{l}-0.006 \\
(1.60)\end{array}$ & \\
\hline Social globalization & & $\begin{array}{c}0.016 \\
(2.87)^{* * *}\end{array}$ & & & & & & $\begin{array}{c}0.015 \\
(3.18)^{* * *}\end{array}$ & & & $\begin{array}{c}0.011 \\
(1.73)^{*}\end{array}$ & & & & & & $\begin{array}{c}0.010 \\
(2.11)^{* *}\end{array}$ & \\
\hline Politicial globalization & & & $\begin{array}{l}0.005 \\
(1.47)\end{array}$ & & & & & $\begin{array}{l}0.002 \\
(0.89)\end{array}$ & & & & $\begin{array}{l}0.001 \\
(0.30)\end{array}$ & & & & & $\begin{array}{c}-1.5 \mathrm{E}-04 \\
(0.05)\end{array}$ & \\
\hline KOF globalization & & & & $\begin{array}{c}0.014 \\
(2.17)^{* *}\end{array}$ & & & & & $\begin{array}{c}0.010 \\
(2.12)^{* *}\end{array}$ & & & & $\begin{array}{l}0.007 \\
(0.99)\end{array}$ & & & & & $\begin{array}{l}0.002 \\
(0.46)\end{array}$ \\
\hline Fraser & & & & & $\begin{array}{c}0.211 \\
(2.63)^{* * *}\end{array}$ & & & & & & & & & $\begin{array}{c}0.189 \\
(2.35)^{* *}\end{array}$ & & & & \\
\hline Fraser (interpolated) & & & & & & $\begin{array}{c}0.156 \\
(3.66)^{* * * *}\end{array}$ & & $\begin{array}{c}0.140 \\
(2.90)^{* * *}\end{array}$ & $\begin{array}{c}0.126 \\
(2.78)^{* * *}\end{array}$ & & & & & & $\begin{array}{c}0.145 \\
(3.46)^{* * *}\end{array}$ & & $\begin{array}{c}0.143 \\
(3.02)^{* * *}\end{array}$ & $\begin{array}{c}0.139 \\
(3.01)^{* * *}\end{array}$ \\
\hline Heritage & & & & & & & $\begin{array}{l}0.010 \\
(1.09)\end{array}$ & & & & & & & & & $\begin{array}{l}0.009 \\
(1.06)\end{array}$ & & \\
\hline Observations & 1412 & 1412 & 14 & 1412 & $4 t$ & 1374 & 535 & 1374 & 1374 & 1412 & 1412 & 1412 & 1412 & 405 & 1374 & 535 & 1374 & 1374 \\
\hline Countries & 71 & 71 & 71 & 71 & 70 & 70 & 71 & 70 & 70 & 71 & 71 & 7 & 71 & 70 & 70 & 71 & 70 & 70 \\
\hline R-sq & 0.33 & 0.33 & 0.33 & 0.33 & 0.33 & 0.33 & 0.40 & 0.34 & 0.33 & 0.33 & 0.34 & 0.33 & 0.3 & 0.33 & 0.34 & 0.40 & 0.34 & 0.34 \\
\hline Turingpoints in \$ & & & & & & & & & & 3583 & 6003 & 3549 & 4588 & 3953 & 4371 & 3116 & 5492 & 4845 \\
\hline
\end{tabular}

Notes: All regressions include dummies for each year. The standard errors are clustered at the country level, except in columns 7, 8, 9, 15, 17, 18 where they were bootstrapped using 1000 replications. Turning point refers to the minimum of per capita GDP. The R-squared reported is a pseudo R-squared. */**/*** indicates significance at the 10/5/1-\% level. 
Table 4 - Granger Causality Tests

\begin{tabular}{lcccc}
\hline & $\begin{array}{c}{[\ldots] \text { Granger-causes }} \\
\text { Physical Integrity Rights }\end{array}$ & 0.45 & \multicolumn{2}{c}{ Empowerment Rights } \\
\hline Economic globalization & 0.00 & 0.85 & 0.00 & 0.05 \\
Social globalization & 0.00 & 0.98 & 0.00 & 0.16 \\
Politicial globalization & 0.00 & 0.70 & 0.00 & 0.00 \\
KOF globalization & 0.00 & 0.53 & 0.00 & 0.00 \\
Fraser & 0.00 & 0.32 & 0.00 & 0.85 \\
Heritage & 0.00 & 0.00 & 0.12 \\
\hline
\end{tabular}

Notes: The table reports p-values for Granger causality tests using two lags. The $\mathrm{H}_{0}$ is that variable A does not Granger-cause B. Therefore, the first two entries indicate that economic globalization Granger-causes physical integrity while physical integrity does not Granger-cause economic globalization.

\section{Table 5 - Marginal Effects}

\begin{tabular}{|c|c|c|c|c|c|c|c|c|c|c|c|c|}
\hline Index value & 0 & 1 & 2 & 3 & 4 & 5 & 6 & 7 & 8 & 9 & 10 & $\mathrm{E}[\mathrm{y}]$ \\
\hline \multicolumn{13}{|l|}{ Physical Integrity } \\
\hline Sample Frequency & 0.043 & 0.051 & 0.074 & 0.091 & 0.132 & 0.137 & 0.140 & 0.168 & 0.164 & & & 5.014 \\
\hline Probability at mean & 2.7E-04 & 0.003 & 0.018 & 0.061 & 0.191 & 0.293 & 0.266 & 0.149 & 0.020 & & & 5.246 \\
\hline Economic globalization & $-9.2 \mathrm{E}-06$ & $-7.7 \mathrm{E}-05$ & $-3.7 \mathrm{E}-04$ & -0.001 & -0.002 & $-5.6 \mathrm{E}-04$ & 0.001 & 0.002 & $4.4 \mathrm{E}-04$ & & & 0.011 \\
\hline $\mathrm{p}$-value & 0.14 & 0.08 & 0.07 & 0.08 & 0.08 & 0.09 & 0.08 & 0.07 & 0.09 & & & 0.07 \\
\hline Social globalization & $-1.2 \mathrm{E}-05$ & $-1.0 \mathrm{E}-04$ & $-4.9 \mathrm{E}-04$ & -0.001 & -0.002 & $-8.3 \mathrm{E}-04$ & 0.002 & 0.003 & $6.4 \mathrm{E}-04$ & & & 0.016 \\
\hline $\mathrm{p}$-value & 0.02 & 0.00 & 0.00 & 0.00 & 0.00 & 0.00 & 0.00 & 0.00 & 0.00 & & & 0.00 \\
\hline Political globalization & $-8.5 E-06$ & $-6.7 \mathrm{E}-05$ & $-3.1 \mathrm{E}-04$ & -0.001 & -0.001 & $-4.6 \mathrm{E}-04$ & 0.001 & 0.002 & $3.9 \mathrm{E}-04$ & & & 0.010 \\
\hline $\mathrm{p}$-value & 0.04 & 0.01 & 0.00 & 0.00 & 0.00 & 0.01 & 0.00 & 0.00 & 0.00 & & & 0.00 \\
\hline KOF globalization & $-1.9 \mathrm{E}-05$ & $-1.5 \mathrm{E}-04$ & $-6.9 \mathrm{E}-04$ & -0.002 & -0.003 & $-1.1 \mathrm{E}-03$ & 0.003 & 0.004 & $8.5 \mathrm{E}-04$ & & & 0.022 \\
\hline $\mathrm{p}$-value & 0.02 & 0.00 & 0.00 & 0.00 & 0.00 & 0.00 & 0.00 & 0.00 & 0.00 & & & 0.00 \\
\hline Fraser & $-8.7 \mathrm{E}-05$ & -0.001 & -0.008 & -0.014 & -0.029 & -0.006 & 0.022 & 0.031 & 0.006 & & & 0.190 \\
\hline p-value & 0.17 & 0.04 & 0.03 & 0.03 & 0.02 & 0.12 & 0.03 & 0.02 & 0.02 & & & 0.02 \\
\hline Fraser (interpolated) & $-1.9 \mathrm{E}-04$ & -0.001 & -0.006 & -0.016 & -0.030 & -0.011 & 0.023 & 0.034 & 0.008 & & & 0.204 \\
\hline p-value & 0.00 & 0.00 & 0.00 & 0.00 & 0.00 & 0.00 & 0.00 & 0.00 & 0.00 & & & 0.00 \\
\hline Heritage & $-8.1 \mathrm{E}-06$ & $-8.5 \mathrm{E}-05$ & -0.001 & -0.001 & -0.002 & 0.000 & 0.002 & 0.003 & $3.1 \mathrm{E}-04$ & & & 0.015 \\
\hline p-value & 0.21 & 0.13 & 0.09 & 0.07 & 0.07 & 0.13 & 0.06 & 0.07 & 0.11 & & & 0.06 \\
\hline \multicolumn{13}{|l|}{ Empowerment } \\
\hline Sample Frequency & 0.005 & 0.007 & 0.017 & 0.036 & 0.042 & 0.063 & 0.062 & 0.105 & 0.159 & 0.216 & 0.288 & 7.831 \\
\hline Probability at mean & $1.6 \mathrm{E}-09$ & $1.2 \mathrm{E}-07$ & $5.8 \mathrm{E}-06$ & $2.2 \mathrm{E}-04$ & 0.002 & 0.019 & 0.056 & 0.174 & 0.334 & 0.319 & 0.095 & 8.158 \\
\hline Social globalization & $-1.1 \mathrm{E}-10$ & $-7.0 \mathrm{E}-09$ & $-2.9 \mathrm{E}-07$ & $-9.1 \mathrm{E}-06$ & $-7.5 \mathrm{E}-05$ & $-4.8 \mathrm{E}-04$ & -0.001 & -0.002 & $-7.8 \mathrm{E}-04$ & $2.4 \mathrm{E}-03$ & $1.9 \mathrm{E}-03$ & 0.012 \\
\hline p-value & 0.54 & 0.47 & 0.42 & 0.25 & 0.19 & 0.10 & 0.08 & 0.09 & 0.11 & 0.10 & 0.08 & 0.08 \\
\hline Fraser & & $-2.2 \mathrm{E}-08$ & $-2.6 \mathrm{E}-06$ & $-6.3 E-05$ & -0.001 & -0.006 & -0.018 & -0.034 & -0.016 & 0.044 & 0.031 & 0.196 \\
\hline p-value & & 0.58 & 0.47 & 0.33 & 0.21 & 0.05 & 0.03 & 0.03 & 0.05 & 0.03 & 0.02 & 0.02 \\
\hline Fraser (interpolated) & $-1.8 \mathrm{E}-09$ & $-6.8 \mathrm{E}-08$ & $-3.6 \mathrm{E}-06$ & $-1.1 \mathrm{E}-04$ & -0.001 & -0.006 & -0.013 & -0.025 & -0.011 & 0.032 & 0.025 & 0.156 \\
\hline $\mathrm{p}$-value & 0.53 & 0.41 & 0.22 & 0.03 & 0.01 & 0.00 & 0.00 & 0.00 & 0.00 & 0.001 & 0.001 & 0.00 \\
\hline
\end{tabular}

Notes: The table reports the marginal effects corresponding to Tables 2 and 3 by index values. The row 'sample frequency' reports the observed frequency in the sample, while 'probability at mean' yields the probability for observing a given index value according to the estimated model. 
Figure 1 - Marginal Effects

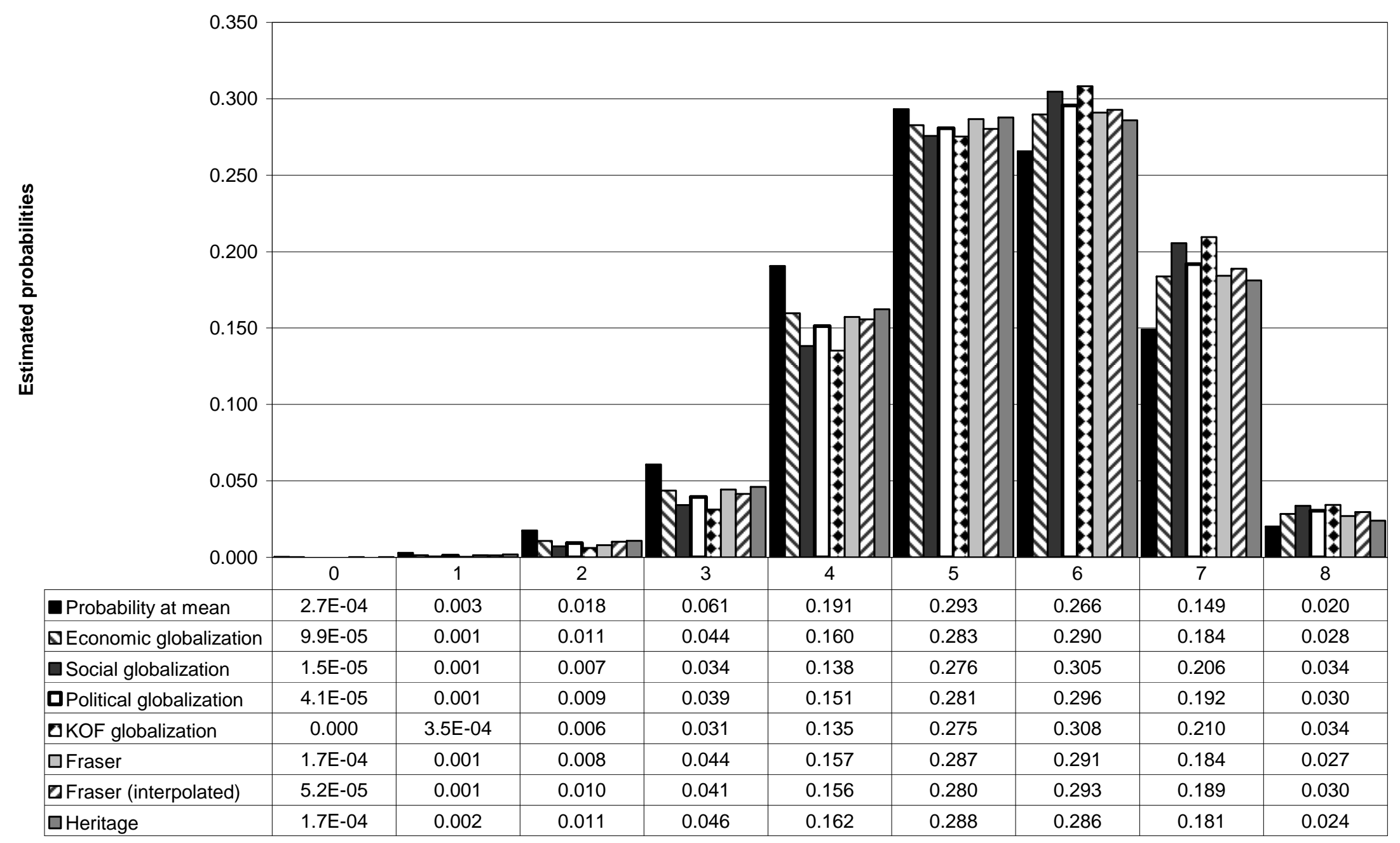

Notes: The figure visualizes the effects of a one standard deviation change of the variables of interest in Table 2 (columns 9-16). 


\section{Appendix A1: Components of the KOF Index of Globalization}

Indices and Variables

A. Economic Globalization

i) Actual Flows

Trade (percent of GDP)

Foreign Direct Investment, flows (percent of GDP)

Foreign Direct Investment, stocks (percent of GDP)

Portfolio Investment (percent of GDP)

Income Payments to Foreign Nationals (percent of GDP)

ii) Restrictions

Hidden Import Barriers

Mean Tariff Rate

Taxes on International Trade (percent of current revenue)

Capital Account Restrictions
Weights

[38\%]

$(50 \%)$

$(19 \%)$

(20\%)

$(23 \%)$

$(17 \%)$

$(21 \%)$

$(50 \%)$

(21\%)

(29\%)

(25\%)

(25\%)

B. Social Globalization

[39\%]

(34\%)

(26\%)

(26\%)

(20\%)

(26\%)

International letters (per capita)

(36\%)

(36\%)

(28\%)

Trade in Newspapers (percent of GDP)

(39\%)

(24\%)

C. Political Globalization [23\%]

Embassies in Country

Membership in International Organizations $\quad$ (28\%)

Participation in U.N. Security Council Missions

International Treaties $\quad$ (25\%)

Notes: The number in parentheses indicates the weight used to derive the indices. Weights may not sum to 100 because of rounding.

Source: Dreher (2006a), Dreher et al. (2008) and http://globalization.kof.ethz.ch/. 


\section{Appendix A2: Areas and Components of the Fraser Economic Freedom Index}

Area 1: Size of Government: Expenditures, Taxes, and Enterprises

A General government consumption spending as a percentage of total consumption

B Transfers and subsidies as a percentage of GDP

C Government enterprises and investment

D Top marginal tax rate

i Top marginal income tax rate

ii Top marginal income and payroll tax rates

Area 2: Legal Structure and Security of Property Rights

A Judicial independence (GCR)

B Impartial courts (GCR)

C Protection of property rights (GCR)

D Military interference in rule of law and the political process (CRG)

E Integrity of the legal system (CRG)

$F$ Legal enforcement of contracts (DB)

G Regulatory restrictions on the sale of real property (DB)

Area 3: Access to Sound Money

A Money Growth

B Standard deviation of inflation

C Inflation: Most recent year

D Freedom to own foreign currency bank accounts

Area 4: Freedom to Trade Internationally

A Taxes on international trade

i. $\quad$ Revenues from trade taxes (\% of trade sector)

ii Mean tariff rate

iii Standard deviation of tariff rates

B Regulatory Trade Barriers

i Non-tariff trade barriers (GCR)

ii Compliance cost of importing and exporting (DB)

C Size of the trade sector relative to expected

D Black-market exchange rates

E International capital market controls

i Foreign ownership/investment restrictions (GCR)

ii Capital controls

Area 5: Regulation of Credit, Labor, and Business

A Credit market regulations

i. Ownership of banks

ii Foreign bank competition

iii Private sector credit

iv Interest rate controls/negative real interest rates

B Labor market regulations

i Minimum wage (DB)

ii Hiring and firing regulations (GCR)

iii Centralized collective bargaining (GCR)

iv $\quad$ Mandated cost of hiring (DB)

$\mathrm{v} \quad$ Mandated cost of worker dismissal (DB)

vi Conscription

C Business Regulations

i Price controls

ii Administrative requirements (GCR)

iii Bureaucracy costs (GCR)

iv Starting a business (DB)

v Extra payments/bribes (GCR)

vi Licensing restrictions (DB)

vii Cost of tax compliance (DB)

Source: Gwartney and Lawson (2008) 


\section{Appendix A3: Components of the Heritage Economic Freedom Index}

\begin{tabular}{|c|c|}
\hline Sub-index & Description \\
\hline Business freedom & $\begin{array}{l}\text { Ability to create, operate, and close an enterprise without } \\
\text { interference from the state. }\end{array}$ \\
\hline Trade freedom & $\begin{array}{l}\text { Ability of citizens to interact freely as buyers and sellers in the } \\
\text { international marketplace }\end{array}$ \\
\hline Fiscal freedom & Burden of government from the revenue side, i.e., taxes \\
\hline Government size & Level of government expenditures as a percentage of GDP \\
\hline Monetary freedom & Combines price stability with an assessment of price controls \\
\hline Investment freedom & $\begin{array}{l}\text { Policies toward the free flow of investment capital (foreign } \\
\text { investment as well as internal capital flows) }\end{array}$ \\
\hline Financial freedom & $\begin{array}{l}\text { Measurement of banking security as well as independence from } \\
\text { government control }\end{array}$ \\
\hline Property rights & $\begin{array}{l}\text { Assessment of the ability of individuals to accumulate private } \\
\text { property, secured by clear laws that are fully enforced by the state }\end{array}$ \\
\hline Freedom from corruption & $\begin{array}{l}\text { Assessment of the perception of corruption (mainly Transparency } \\
\text { Internation) }\end{array}$ \\
\hline Labour freedom & $\begin{array}{l}\text { Ability of individuals to work as much as they want and wherever } \\
\text { they want }\end{array}$ \\
\hline
\end{tabular}

Source: Miller and Holmes (2009: 11-15 and 441-451) 


\section{Appendix B: Sources and Definitions}

\begin{tabular}{|c|}
\hline Variable \\
\hline Physical integrity \\
\hline Empowerment index \\
\hline Democracy \\
\hline Population (log) \\
\hline GDP p.c. (log) \\
\hline Legal origin \\
\hline War \\
\hline \multirow{5}{*}{$\begin{array}{l}\text { Economic globalization } \\
\text { Social globalization } \\
\text { Politicial globalization } \\
\text { KOF globalization } \\
\text { Fraser }\end{array}$} \\
\hline \\
\hline \\
\hline \\
\hline \\
\hline Heritage \\
\hline Additional Variables used in the EBA \\
\hline Age of democracy \\
\hline Age of parties \\
\hline Area (log) \\
\hline British colony \\
\hline Catholic Share \\
\hline Constituency \\
\hline Debt service \\
\hline Diversified exporters \\
\hline Dominant religion \\
\hline Election year, legislative \\
\hline Ethnic fractionalization \\
\hline FDI \\
\hline Federalism \\
\hline Fractionalization \\
\hline
\end{tabular}

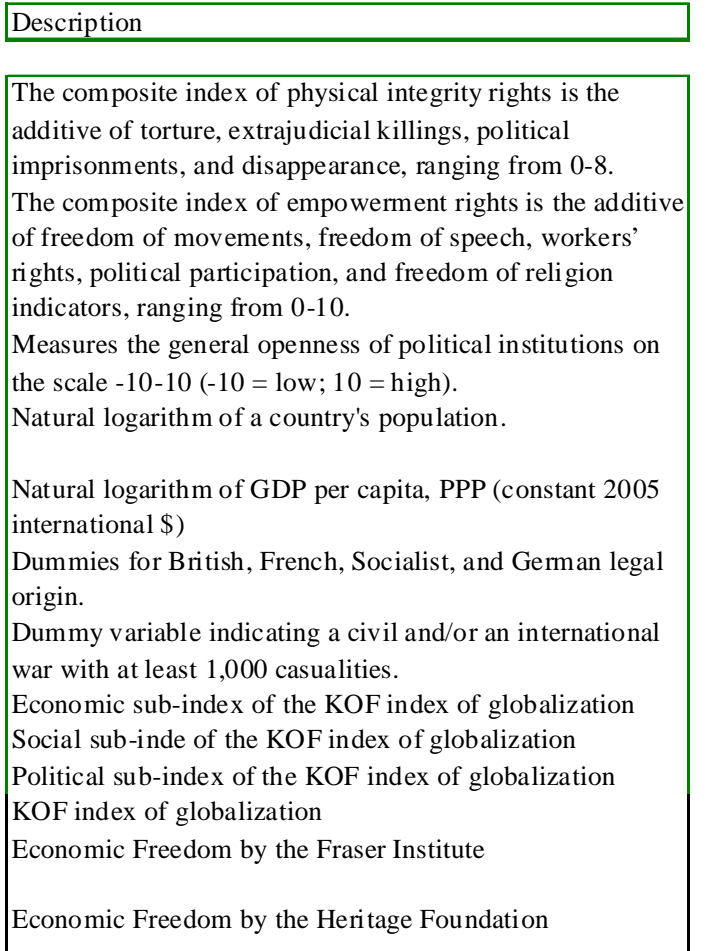

Defined as: AGE = (2000 - DEM_AGE)/200 and varying between 0 and 1 , with US being the oldest democracy (value of 1).

Average age of political parties.

Natural logarithm of land area (square kilometer).

Former British colony.

Share of catholics in population.

Indicates whether the constituencies of the senators are states/provinces.

Public and publicly guaranteed debt service (percent of GNI).

Dummy for diversified exporters.

Percent of dominant religion.

Dummy for legislative elections.

Index of ethnic fractionalization.

Foreign direct investment, net inflows (percent of GDP).

Dummy for federal states.

Index of ethnolinguistic fractionalization, approximating the level of lack of ethnic and linguistic cohesion within a country, ranging from 0 (homogeneous) to 1 (strongly fractionalized) and averaging 5 different indexes.

\section{Source}

Cingranelli and Richards (2006)

Cingranelli and Richards (2006)

Marshall and

Jaggers (2000)

World Bank

(2009)

World Bank

(2009)

Easterly and

Sewadeh (2001)

Gleditsch et al.

(2002)

Dreher (2006a)

Dreher (2006a)

Dreher (2006a)

Dreher (2006a)

Gwartney and

Lawson (2008)

Miller and

Holmes (2009)

Persson and

Tabellini (2003)

Beck et al. (2001)

World Bank

(2009)

CEPII (2010)

Persson and

Tabellini (2003)

Beck et al. (2001)

World Bank

(2009)

Easterly and

Sewadeh (2001)

Alesina et al.

(2003)

Beck et al. (2001)

Alesina et al.

(2003)

World Bank

(2009)

Norris (2009)

Persson and

Tabellini (2003) 


\begin{tabular}{|c|}
\hline Variable \\
\hline Gap in schooling \\
\hline Government debt \\
\hline Government Fractionalization \\
\hline Government transfers \\
\hline Growth \\
\hline Human Development Indicator \\
\hline Iberian colony \\
\hline IMF program \\
\hline Infant mortality \\
\hline Investment \\
\hline Investment growth \\
\hline Language fractionalization \\
\hline Left government \\
\hline Life expectancy \\
\hline Military dictator \\
\hline New state \\
\hline $\begin{array}{l}\text { Number of human rights } \\
\text { organizations }\end{array}$ \\
\hline Population growth \\
\hline Post election, executive \\
\hline Post election, legislature \\
\hline Pre-election, executive \\
\hline Pre-election, legislature \\
\hline Primary schooling \\
\hline Protestant share \\
\hline Religious fractionalization \\
\hline
\end{tabular}

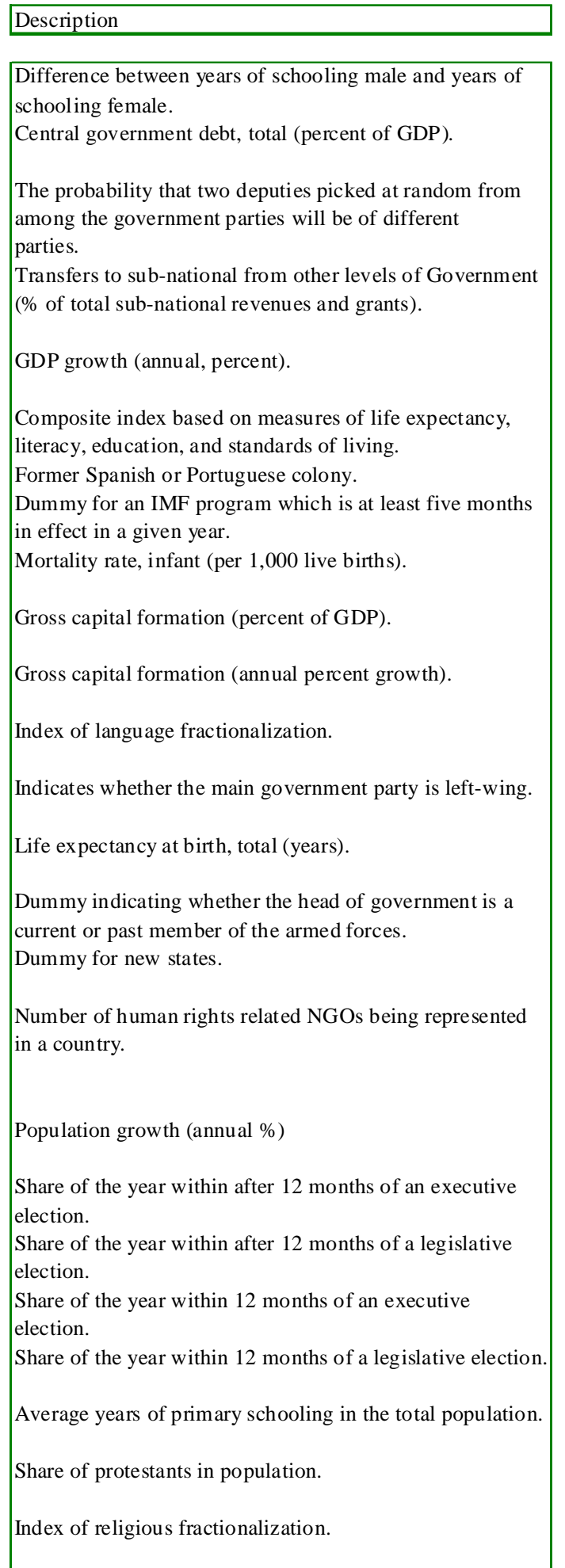

\begin{tabular}{|l|}
\hline Source \\
\hline \\
\hline Barro and Lee \\
(2000) \\
World Bank \\
(2009) \\
Beck et al. (2001) \\
\\
IMF's \\
Government \\
Finance Statistics \\
World Bank \\
(2009) \\
United Nations \\
(2005) \\
CEPII (2010) \\
Dreher (2006b) \\
World Bank \\
(2009) \\
World Bank \\
(2009) \\
World Bank \\
(2009) \\
Alesina et al. \\
(2003) \\
Beck et al. (2001) \\
World Bank \\
(2009) \\
Cheibub et al. \\
(2010) \\
Gallup et al. \\
(2001) \\
Union of \\
International \\
Associations \\
(2000) \\
World Bank \\
(2009) \\
Dreher and \\
Vaubel (2009) \\
Dreher and \\
Vaubel (2009) \\
Dreher and \\
Vaubel (2009) \\
Dreher and \\
Vaubel (2009) \\
Barro and Lee \\
(2000) \\
\hline
\end{tabular}


Variable

Revenue decentralization

Special interests

Sub-national Tax Revenue

Tiers

Tiers, average

Trade

Urban population

Urban population growth

Vertical imbalance

World Bank projects

Years in office

Years left

Years of independence
Description

Sub-national Revenues (\% of total revenues)

Dummy for special interest executive parties.

Sub-national Tax Revenue (\% of total sub-national revenues and grants).

Number of government tiers.

Average area first tier units (thousands square kilometers per unit).

Exports and Imports (in percent of GDP).

Urban population (percent of total).

Urban population growth (annual \%)

Intergovernmental transfers as a share of sub-national expenditures.

Number of World Bank projects at least five months in effect in a given year.

Indicates the number of years the government chief executive has been in office.

Number of years the government chief executive remains in office.

Ranging from 0 to 250 (the latter value is used for all noncolonized countries).
Source

IMF's

Government

Finance Statistics

Beck et al. (2001)

IMF's

Government

Finance Statistics

Treisman (2000)

Treisman (2000)

World Bank

(2009)

World Bank

(2009)

World Bank

(2009)

IMF's

Government

Finance Statistics

Boockmann and

Dreher (2003)

Beck et al. (2001)

Beck et al. (2001)

Persson and

Tabellini (2003) 


\section{Appendix C1: EBA Results - Physical Integrity Rights}

\begin{tabular}{|c|c|c|c|c|c|c|}
\hline Variable & Avg. Beta & Avg.Std.E. & \%Sign. & CDF-U & lwr Bound & upr Bound \\
\hline Age of democracy & 0.8365 & 0.3672 & 81.20 & 0.9275 & -13.954 & 53.211 \\
\hline FDI & 0.0187 & 0.0114 & 59.56 & 0.9113 & -0.627 & 1.328 \\
\hline Years in office & 0.0109 & 0.0074 & 44.22 & 0.9071 & -0.295 & 3.094 \\
\hline Years of independence & 0.0015 & 0.0009 & 68.83 & 0.9052 & -0.067 & 0.049 \\
\hline Tiers & 0.1439 & 0.0829 & 56.53 & 0.9030 & -2.528 & 5.274 \\
\hline Iberian colony & -0.2640 & 0.1558 & 61.76 & 0.9003 & -12.400 & 15.535 \\
\hline Number of human rights organizations & 0.0053 & 0.0029 & 70.79 & 0.8894 & -0.145 & 0.434 \\
\hline Tiers, average & 0.0006 & 0.0004 & 45.83 & 0.8851 & -0.021 & 0.107 \\
\hline IMF program & -0.1489 & 0.1026 & 53.95 & 0.8751 & -61.358 & 3.024 \\
\hline Protestant share & 0.0077 & 0.0056 & 43.29 & 0.8549 & -0.374 & 0.286 \\
\hline Vertical integration & 0.0039 & 0.0041 & 24.27 & 0.8434 & -0.594 & 0.902 \\
\hline Dominant religion & -0.0051 & 0.0039 & 48.08 & 0.8379 & -0.207 & 0.163 \\
\hline Government debt & 0.0023 & 0.0024 & 57.41 & 0.8293 & -0.321 & 0.097 \\
\hline Constituency & -0.2508 & 0.2271 & 34.26 & 0.8281 & -193.93 & 70.125 \\
\hline Catholic Share & 0.0023 & 0.0024 & 27.83 & 0.8179 & -0.052 & 0.233 \\
\hline Growth & 0.0070 & 0.0104 & 19.80 & 0.7813 & -0.303 & 0.745 \\
\hline Pre-election, executive & -0.1484 & 0.1737 & 28.80 & 0.7715 & -234.18 & 7.449 \\
\hline Government transfers & 0.0014 & 0.0043 & 13.26 & 0.7697 & -0.418 & 0.574 \\
\hline Infant mortality & -0.0041 & 0.0112 & 31.80 & 0.7684 & -11.408 & 5.055 \\
\hline Trade & 0.0016 & 0.0019 & 11.21 & 0.7538 & -0.056 & 0.136 \\
\hline New state & -0.0612 & 0.0694 & 23.02 & 0.7469 & -1.842 & 2.881 \\
\hline Religious fractionalization & 0.1648 & 0.3584 & 38.47 & 0.7439 & -20.036 & 18.996 \\
\hline Pre-election, legislature & 0.0854 & 0.1125 & 16.48 & 0.7437 & -4.162 & 3.051 \\
\hline Urban population & -0.0042 & 0.0047 & 12.64 & 0.7426 & -0.366 & 0.063 \\
\hline Government Fractionalization & 0.1424 & 0.1895 & 9.77 & 0.7304 & -7.008 & 13.444 \\
\hline Revenue decentralization & 0.0076 & 0.0091 & 13.17 & 0.7217 & -0.888 & 1.644 \\
\hline Investment growth & 0.0015 & 0.0026 & 27.07 & 0.7162 & -0.218 & 3.110 \\
\hline Life expectancy & -0.0081 & 0.0210 & 14.19 & 0.7111 & -5.402 & 3.091 \\
\hline Urban population growth & 0.0303 & 0.0370 & 17.50 & 0.7094 & -3.477 & 14.835 \\
\hline Primary schooling & 0.0497 & 0.0731 & 8.02 & 0.6909 & -8.402 & 22.709 \\
\hline Military dictator & 0.1423 & 0.1906 & 7.40 & 0.6906 & -3.131 & 19.358 \\
\hline Federalism & 0.0511 & 0.1479 & 15.80 & 0.6830 & -12.468 & 3.966 \\
\hline Language fractionalization & 0.1493 & 0.2614 & 3.75 & 0.6795 & -7.417 & 31.990 \\
\hline Post election, executive & -0.1151 & 0.1754 & 3.76 & 0.6750 & -8.998 & 66.803 \\
\hline Left government & -0.0320 & 0.0876 & 3.75 & 0.6746 & -1.976 & 5.480 \\
\hline Area (log) & 0.0209 & 0.0426 & 9.42 & 0.6703 & -4.803 & 3.405 \\
\hline Debt service & -0.0080 & 0.0145 & 21.66 & 0.6548 & -0.941 & 0.880 \\
\hline Sub-national Tax Revenue & -0.0010 & 0.0041 & 2.54 & 0.6519 & -0.426 & 0.775 \\
\hline Age of parties & 0.0009 & 0.0022 & 6.58 & 0.6448 & -0.092 & 0.069 \\
\hline Years left & -0.0063 & 0.0321 & 0.25 & 0.6025 & -16.889 & 0.683 \\
\hline Gap in schooling & -0.0440 & 0.0305 & 17.06 & 0.5897 & -23.311 & 23.292 \\
\hline Ethnic fractionalization & -0.0582 & 0.2634 & 3.42 & 0.5821 & -7.036 & 15.534 \\
\hline World Bank projects & -0.0011 & 0.0398 & 7.17 & 0.5787 & -3.240 & 0.890 \\
\hline Post election, legislature & -0.0443 & 0.1236 & 6.25 & 0.5733 & -5.827 & 13.714 \\
\hline Diversified exporters & -0.0044 & 0.1205 & 5.17 & 0.5462 & -5.092 & 5.360 \\
\hline British colony & -0.0259 & 0.1559 & 6.38 & 0.5462 & -10.962 & 60.689 \\
\hline Human Development Indicator & 0.4688 & 1.2645 & 9.68 & 0.5459 & -144.76 & 1045.7 \\
\hline Election year, legislative & 0.0026 & 0.0949 & 0.87 & 0.5445 & -14.210 & 14.288 \\
\hline Investment & 0.0015 & 0.0072 & 16.29 & 0.5378 & -0.639 & 0.691 \\
\hline Population growth & -0.0138 & 0.0715 & 26.63 & 0.5351 & -2.475 & 12.431 \\
\hline Special interests & 0.0067 & 0.1697 & 6.61 & 0.5350 & -6.041 & 8.163 \\
\hline Fractionalization & -0.0006 & 0.2898 & 1.65 & 0.5033 & -7.657 & 13.139 \\
\hline
\end{tabular}




\section{Appendix C2: EBA Results - Empowerment Rights}

\begin{tabular}{|c|c|c|c|c|c|c|}
\hline Variable & Avg. B eta & Avg.Std.E. & \% Sign. & CDF-U & lwr Bound & upr Bound \\
\hline Protestant share & 0.0138 & 0.0053 & 84.42 & 0.9674 & -0.183 & 0.163 \\
\hline Population growth & -0.1008 & 0.0574 & 65.72 & 0.9188 & -13.695 & 6.616 \\
\hline Number of human rights organizations & 0.0065 & 0.0037 & 63.63 & 0.9138 & -0.900 & 0.148 \\
\hline Dominant religion & -0.0066 & 0.0035 & 66.07 & 0.9064 & -0.346 & 0.115 \\
\hline Left government & 0.1407 & 0.0950 & 72.22 & 0.9038 & -3.338 & 4.089 \\
\hline Growth & -0.0168 & 0.0117 & 39.05 & 0.8935 & -0.730 & 0.210 \\
\hline Religious fractionalization & 0.4524 & 0.3263 & 62.62 & 0.8737 & -22.125 & 65.972 \\
\hline Government Fractionalization & -0.2141 & 0.1838 & 28.06 & 0.8667 & -7.440 & 6.404 \\
\hline Urban population growth & -0.0554 & 0.0341 & 55.48 & 0.8627 & -3.192 & 4.437 \\
\hline World Bank projects & 0.0586 & 0.0465 & 48.69 & 0.8615 & -6.354 & 2.339 \\
\hline Iberian colony & -0.2574 & 0.1597 & 46.12 & 0.8398 & -23.178 & 6.987 \\
\hline Vertical integration & 0.0046 & 0.0045 & 29.21 & 0.8278 & -0.301 & 2.012 \\
\hline Go vernment transfers & 0.0041 & 0.0046 & 27.07 & 0.8152 & -1.758 & 0.526 \\
\hline Urban population & -0.0041 & 0.0042 & 13.90 & 0.7997 & -0.247 & 0.260 \\
\hline Tiers, average & 0.0002 & 0.0005 & 9.01 & 0.7653 & -0.801 & 0.044 \\
\hline Government debt & 0.0017 & 0.0026 & 22.32 & 0.7576 & -0.094 & 0.276 \\
\hline IMF program & -0.0953 & 0.1073 & 9.94 & 0.7535 & -6.837 & 7.623 \\
\hline British colony & 0.1414 & 0.1740 & 11.41 & 0.7456 & -5.149 & 10.653 \\
\hline FDI & 0.0098 & 0.0164 & 13.20 & 0.7430 & -0.418 & 3.334 \\
\hline Years left & -0.0187 & 0.0316 & 31.74 & 0.7405 & -1.294 & 1.006 \\
\hline Language fractionalization & 0.2198 & 0.2485 & 11.92 & 0.7378 & -4.536 & 10.777 \\
\hline Age of democracy & 0.3776 & 0.4188 & 38.61 & 0.7373 & -43.898 & 16.941 \\
\hline Catholic Share & 0.0020 & 0.0029 & 9.99 & 0.7335 & -0.112 & 0.320 \\
\hline Pre-election, executive & -0.0973 & 0.1762 & 4.61 & 0.7238 & -5.282 & 8.287 \\
\hline Trade & -0.0011 & 0.0018 & 8.02 & 0.7209 & -0.185 & 0.192 \\
\hline Investment & -0.0054 & 0.0080 & 28.28 & 0.7110 & -0.236 & 1.762 \\
\hline Post election, legislature & 0.0607 & 0.1305 & 3.26 & 0.7060 & -4.233 & 9.509 \\
\hline Revenue decentralization & 0.0073 & 0.0108 & 16.55 & 0.7051 & -3.409 & 4.329 \\
\hline Sub-national Tax Revenue & -0.0022 & 0.0042 & 8.18 & 0.6894 & -0.279 & 0.699 \\
\hline Years in office & 0.0050 & 0.0099 & 14.24 & 0.6821 & -0.374 & 2.757 \\
\hline Ethnic fractionalization & -0.1489 & 0.2794 & 11.85 & 0.6779 & -184.82 & 10.813 \\
\hline Age of parties & 0.0010 & 0.0022 & 4.44 & 0.6751 & -0.445 & 0.975 \\
\hline Diversified exporters & -0.0724 & 0.1356 & 5.73 & 0.6701 & -3.934 & 3.291 \\
\hline Human Development Indicator & 0.9865 & 1.2689 & 14.12 & 0.6681 & -48.963 & 247.19 \\
\hline Military dictator & -0.0646 & 0.2219 & 5.48 & 0.6313 & -16.558 & 11.389 \\
\hline Area $(\log )$ & -0.0263 & 0.0430 & 9.57 & 0.6203 & -1.390 & 5.204 \\
\hline Election year, legislative & 0.0148 & 0.0948 & 3.70 & 0.6164 & -2.511 & 6.684 \\
\hline Federalism & 0.0242 & 0.1413 & 4.83 & 0.5960 & -12.151 & 19.284 \\
\hline Years of independence & 0.0001 & 0.0011 & 10.81 & 0.5883 & -0.035 & 0.028 \\
\hline Tiers & -0.0546 & 0.0913 & 10.45 & 0.5871 & -6.423 & 1.785 \\
\hline Life expectancy & 0.0022 & 0.0231 & 43.86 & 0.5837 & -7.649 & 4.962 \\
\hline Post election, executive & 0.0310 & 0.1844 & 1.90 & 0.5772 & -17.027 & 27.486 \\
\hline Investment growth & 0.0003 & 0.0034 & 3.05 & 0.5480 & -0.307 & 0.111 \\
\hline Infant mortality & -0.0026 & 0.0071 & 24.82 & 0.5462 & -1.243 & 1.865 \\
\hline Constituency & 0.0901 & 0.2303 & 18.81 & 0.5384 & -56.023 & 34.802 \\
\hline Fractionalization & -0.0490 & 0.2994 & 3.90 & 0.5377 & -10.273 & 22.135 \\
\hline Special interests & 0.0432 & 0.1500 & 6.20 & 0.5361 & -8.563 & 9.951 \\
\hline New state, dummy & 0.0020 & 0.0759 & 3.14 & 0.5176 & -2.059 & 3.109 \\
\hline Gap in schooling & -0.0193 & 0.0259 & 7.15 & 0.5149 & -19.533 & 4.687 \\
\hline Debt service & 0.0017 & 0.0176 & 7.88 & 0.5085 & -0.623 & 2.018 \\
\hline Pre-election, legislature & -0.0260 & 0.1228 & 3.86 & 0.5021 & -6.475 & 13.166 \\
\hline Primary schooling & -0.0077 & 0.0771 & 7.18 & 0.5013 & -6.825 & 3.256 \\
\hline
\end{tabular}




\section{Bisher erschienene Diskussionspapiere}

Nr. 115: Dreher, Axel; Gassebner, Martin; Siemers, Lars-H. R.: Globalization, Economic Freedom and Human Rights, Oktober 2010

Nr. 114: Dreher, Axel; Mikosch, Heiner; Voigt, Stefan: Membership has its Privileges - The Effect of Membership in International Organizations on FDI, Oktober 2010

Nr. 113: Fuchs, Andreas; Klann, Nils-Hendrik: Paying a Visit: The Dalai Lama Effect on International Trade, Oktober 2010

Nr. 112: Freitag, Stephan: Choosing an Anchor Currency for the Pacific, Oktober 2010

Nr. 111: Nunnenkamp, Peter; Öhler, Hannes: Throwing Foreign Aid at HIV/AIDS in Developing Countries: Missing the Target?, August 2010

Nr. 110: Ohr, Renate; Zeddies, Götz: „Geschäftsmodell Deutschland“ und außenwirtschaftliche Ungleichgewichte in der EU, Juli 2010

Nr. 109: Nunnenkamp, Peter; Öhler, Hannes: Funding, Competition and the Efficiency of NGOs: An Empirical Analysis of Non-charitable Expenditure of US NGOs Engaged in Foreign Aid, Juli 2010

Nr. 108: Krenz, Astrid: La Distinction reloaded: Returns to Education, Family Background, Cultural and Social Capital in Germany, Juli 2010

Nr. 107: Krenz, Astrid: Services sectors' agglomeration and its interdependence with industrial agglomeration in the European Union, Juli 2010

Nr. 106: Krenz, Astrid; Rübel, Gerhard: Industrial Localization and Countries' Specialization in the European Union: An Empirical Investigation, Juli 2010

Nr. 105: Schinke, Jan Christian: Follow the Sun! How investments in solar power plants in Sicily can generate high returns of investments and help to prevent global warming, Juni 2010

Nr. 104: Dreher, Axel; Sturm, Jan-Egbert; Vreeland, James Raymon: Does membership on the Security Council influence IMF conditionality?, Juni 2010

Nr. 103: Öhler, Hannes; Nunnenkamp, Peter; Dreher, Axel: Does Conditionality Work? A Test for an Innovative US Aid Scheme, Juni 2010

Nr. 102: Gehringer, Agnieszka: Pecuniary Knowledge Externalities in a New Taxonomy: Knowledge Interactions in a Vertically Integrated System, Juni 2010

Nr. 101: Gehringer, Agnieszka: Pecuniary Knowledge Externalities across European Countries - are there leading Sectors?, Juni 2010

Nr. 100: Gehringer, Agnieszka: Pecuniary Knowledge Externalities and Innovation: Intersectoral Linkages and their Effects beyond Technological Spillovers, Juni 2010

Nr. 99: Dreher, Axel; Nunnenkamp, Peter; Öhler, Hannes: Why it pays for aid recipients to take note of the Millennium Challenge Corporation: Other donors do!, April 2010

Nr. 98: Baumgarten, Daniel; Geishecker, Ingo; Görg, Holger: Offshoring, tasks, and the skill-wage pattern, März 2010

Nr. 97: Dreher, Axel; Klasen, Stephan; Raymond, James; Werker, Eric: The costs of favoritism: Is politically-driven aid less effective?, März 2010

Nr. 96: Dreher, Axel; Nunnenkamp, Peter; Thiele, Rainer: Are 'New' Donors Different? Comparing the Allocation of Bilateral Aid between Non-DAC and DAC Donor Countries, März 2010

Nr. 95: Lurweg, Maren; Westermeier, Andreas: Jobs Gained and Lost through Trade - The Case of Germany, März 2010

Nr. 94: Bernauer, Thomas; Kalbhenn, Anna; Koubi, Vally; Ruoff, Gabi: On Commitment Levels and Compliance Mechanisms - Determinants of Participation in Global Environmental Agreements, Januar 2010 
Nr. 93: Cho, Seo-Young: International Human Rights Treaty to Change Social Patterns - The Convention on the Elimination of All Forms of Discrimination against Women, Januar 2010

Nr. 92: $\quad$ Dreher, Axel; Nunnenkamp, Peter; Thiel, Susann; Thiele, Rainer: Aid Allocation by German NGOs: Does the Degree of Public Refinancing Matter?, Januar 2010

Nr. 91: Bjørnskov, Christian; Dreher, Axel; Fischer, Justina A. V.; Schnellenbach, Jan: On the relation between income inequality and happiness: Do fairness perceptions matter?, Dezember 2009

Nr. 90: Geishecker, Ingo: Perceived Job Insecurity and Well-Being Revisited: Towards Conceptual Clarity, Dezember 2009

Nr. 89: Kühl, Michael: Excess Comovements between the Euro/US dollar and British pound/US dollar exchange rates, November 2009

Nr. 88: $\quad$ Mourmouras, Alex, Russel, Steven H.: Financial Crises, Capital Liquidation and the Demand for International Reserves, November 2009

Nr. 87: Goerke, Laszlo, Pannenberg, Markus: An Analysis of Dismissal Legislation: Determinants of Severance Pay in West Germany, November 2009

Nr. 86: Marchesi, Silvia, Sabani, Laura, Dreher, Axel: Read my lips: the role of information transmission in multilateral reform design, Juni 2009

Nr. 85: Heinig, Hans Michael: Sind Referenden eine Antwort auf das Demokratiedilemma der EU?, Juni 2009

Nr. 84: El-Shagi, Makram: The Impact of Fixed Exchange Rates on Fiscal Discipline, Juni 2009

Nr. 83: Schneider, Friedrich: Is a Federal European Constitution for an Enlarged European Union Necessary? Some Preliminary Suggestions using Public Choice Analysis, Mai 2009

Nr. 82: Vaubel, Roland: Nie sollst Du mich befragen? Weshalb Referenden in bestimmten Politikbereichen - auch in der Europapolitik - möglich sein sollten, Mai 2009

Nr. 81: Williamson, Jeffrey G.: History without Evidence: Latin American Inequality since 1491, Mai 2009

Nr. 80: Erdogan, Burcu: How does the European Integration affect the European Stock Markets?, April 2009

Nr. 79: Oelgemöller, Jens; Westermeier, Andreas: RCAs within Western Europe, März 2009

Nr. 78: Blonski, Matthias; Lilienfeld-Toal, Ulf von: Excess Returns and the Distinguished Player Paradox, Oktober 2008

Nr. 77: Lechner, Susanne; Ohr, Renate: The Right of Withdrawal in the Treaty of Lisbon: A game theoretic reflection on different decision processes in the EU, Oktober 2008

Nr. 76: Kühl, Michael: Strong comovements of exchange rates: Theoretical and empirical cases when currencies become the same asset, Juli 2008

Nr. 75: Höhenberger, Nicole; Schmiedeberg, Claudia: Structural Convergence of European Countries, Juli 2008

Nr. 74: Nowak-Lehmann D., Felicitas; Vollmer, Sebastian; Martinez-Zarzoso, Inmaculada: Does Comparative Advantage Make Countries Competitive? A Comparison of China and Mexico, Juli 2008

Nr. 73: Fendel, Ralf; Lis, Eliza M.; Rülke, Jan-Christoph: Does the Financial Market Believe in the Phillips Curve? - Evidence from the G7 countries, Mai 2008

Nr. 72: Hafner, Kurt A.: Agglomeration Economies and Clustering - Evidence from German Firms, Mai 2008

Nr. 71: Pegels, Anna: Die Rolle des Humankapitals bei der Technologieübertragung in Entwicklungsländer, April 2008 
Nr. 70: Grimm, Michael; Klasen, Stephan: Geography vs. Institutions at the Village Level, Februar 2008

Nr. 69: Van der Berg, Servaas: How effective are poor schools? Poverty and educational outcomes in South Africa, Januar 2008

Nr. 68: Kühl, Michael: Cointegration in the Foreign Exchange Market and Market Efficiency since the Introduction of the Euro: Evidence based on bivariate Cointegration Analyses, Oktober 2007

Nr. 67: Hess, Sebastian; Cramon-Taubadel, Stephan von: Assessing General and Partial Equilibrium Simulations of Doha Round Outcomes using Meta-Analysis, August 2007

Nr. 66: Eckel, Carsten: International Trade and Retailing: Diversity versus Accessibility and the Creation of "Retail Deserts", August 2007

Nr. 65: Stoschek, Barbara: The Political Economy of Enviromental Regulations and Industry Compensation, Juni 2007

Nr. 64: Martinez-Zarzoso, Inmaculada; Nowak-Lehmann D., Felicitas; Vollmer, Sebastian: The Log of Gravity Revisited, Juni 2007

Nr. 63: Gundel, Sebastian: Declining Export Prices due to Increased Competition from NIC Evidence from Germany and the CEEC, April 2007

Nr. 62: Wilckens, Sebastian: Should WTO Dispute Settlement Be Subsidized?, April 2007

Nr.61: Schöller, Deborah: Service Offshoring: A Challenge for Employment? Evidence from Germany, April 2007

Nr. 60: Janeba, Eckhard: Exports, Unemployment and the Welfare State, März 2007

Nr. 59: Lambsdoff, Johann Graf; Nell, Mathias: Fighting Corruption with Asymmetric Penalties and Leniency, Februar 2007

Nr. 58: Köller, Mareike: Unterschiedliche Direktinvestitionen in Irland - Eine theoriegestützte Analyse, August 2006

Nr. 57: Entorf, Horst; Lauk, Martina: Peer Effects, Social Multipliers and Migrants at School: An International Comparison, März 2007 (revidierte Fassung von Juli 2006)

Nr. 56: Görlich, Dennis; Trebesch, Christoph: Mass Migration and Seasonality Evidence on Moldova's Labour Exodus, Mai 2006

Nr. 55: Brandmeier, Michael: Reasons for Real Appreciation in Central Europe, Mai 2006

Nr. 54: Martínez-Zarzoso, Inmaculada; Nowak-Lehmann D., Felicitas: Is Distance a Good Proxy for Transport Costs? The Case of Competing Transport Modes, Mai 2006

Nr. 53: Ahrens, Joachim; Ohr, Renate; Zeddies, Götz: Enhanced Cooperation in an Enlarged EU, April 2006

Nr. 52: Stöwhase, Sven: Discrete Investment and Tax Competition when Firms shift Profits, April 2006

Nr. 51: Pelzer, Gesa: Darstellung der Beschäftigungseffekte von Exporten anhand einer InputOutput-Analyse, April 2006

Nr. 50: Elschner, Christina; Schwager, Robert: A Simulation Method to Measure the Tax Burden on Highly Skilled Manpower, März 2006

Nr. 49: Gaertner, Wulf; Xu, Yongsheng: A New Measure of the Standard of Living Based on Functionings, Oktober 2005

Nr. 48: Rincke, Johannes; Schwager, Robert: Skills, Social Mobility, and the Support for the Welfare State, September 2005

Nr. 47: Bose, Niloy; Neumann, Rebecca: Explaining the Trend and the Diversity in the Evolution of the Stock Market, Juli 2005 
Nr. 46: Kleinert, Jörn; Toubal, Farid: Gravity for FDI, Juni 2005

Nr. 45: Eckel, Carsten: International Trade, Flexible Manufacturing and Outsourcing, Mai 2005

Nr. 44: Hafner, Kurt A.: International Patent Pattern and Technology Diffusion, Mai 2005

Nr. 43: Nowak-Lehmann D., Felicitas; Herzer, Dierk; Martínez-Zarzoso, Inmaculada; Vollmer, Sebastian: Turkey and the Ankara Treaty of 1963: What can Trade Integration Do for Turkish Exports, Mai 2005

Nr. 42: Südekum, Jens: Does the Home Market Effect Arise in a Three-Country Model?, April 2005

Nr. 41: Carlberg, Michael: International Monetary Policy Coordination, April 2005

Nr. 40: Herzog, Bodo: Why do bigger countries have more problems with the Stability and Growth Pact?, April 2005

Nr. 39: Marouani, Mohamed A.: The Impact of the Mulitfiber Agreement Phaseout on Unemployment in Tunisia: a Prospective Dynamic Analysis, Januar 2005

Nr. 38: Bauer, Philipp; Riphahn, Regina T.: Heterogeneity in the Intergenerational Transmission of Educational Attainment: Evidence from Switzerland on Natives and Second Generation Immigrants, Januar 2005

Nr. 37: Büttner, Thiess: The Incentive Effect of Fiscal Equalization Transfers on Tax Policy, Januar 2005

Nr. 36: Feuerstein, Switgard; Grimm, Oliver: On the Credibility of Currency Boards, Oktober 2004

Nr. 35: Michaelis, Jochen; Minich, Heike: Inflationsdifferenzen im Euroraum - eine Bestandsaufnahme, Oktober 2004

Nr. 34: Neary, J. Peter: Cross-Border Mergers as Instruments of Comparative Advantage, Juli 2004

Nr. 33: Bjorvatn, Kjetil; Cappelen, Alexander W.: Globalisation, inequality and redistribution, Juli 2004

Nr. 32: Stremmel, Dennis: Geistige Eigentumsrechte im Welthandel: Stellt das TRIPs-Abkommen ein Protektionsinstrument der Industrieländer dar?, Juli 2004

Nr. 31: Hafner, Kurt: Industrial Agglomeration and Economic Development, Juni 2004

Nr. 30: Martinez-Zarzoso, Inmaculada; Nowak-Lehmann D., Felicitas: MERCOSUR-European Union Trade: How Important is EU Trade Liberalisation for MERCOSUR's Exports?, Juni 2004

Nr. 29: Birk, Angela; Michaelis, Jochen: Employment- and Growth Effects of Tax Reforms, Juni 2004

Nr. 28: Broll, Udo; Hansen, Sabine: Labour Demand and Exchange Rate Volatility, Juni 2004

Nr. 27: Bofinger, Peter; Mayer, Eric: Monetary and Fiscal Policy Interaction in the Euro Area with different assumptions on the Phillips curve, Juni 2004

Nr. 26: Torlak, Elvisa: Foreign Direct Investment, Technology Transfer and Productivity Growth in Transition Countries, Juni 2004

Nr. 25: Lorz, Oliver; Willmann, Gerald: On the Endogenous Allocation of Decision Powers in Federal Structures, Juni 2004

Nr. 24: Felbermayr, Gabriel J.: Specialization on a Technologically Stagnant Sector Need Not Be Bad for Growth, Juni 2004

Nr. 23: Carlberg, Michael: Monetary and Fiscal Policy Interactions in the Euro Area, Juni 2004

Nr. 22: Stähler, Frank: Market Entry and Foreign Direct Investment, Januar 2004

Nr. 21: Bester, Helmut; Konrad, Kai A.: Easy Targets and the Timing of Conflict, Dezember 2003

Nr. 20: Eckel, Carsten: Does globalization lead to specialization, November 2003 
Nr. 19: Ohr, Renate; Schmidt, André: Der Stabilitäts- und Wachstumspakt im Zielkonflikt zwischen fiskalischer Flexibilität und Glaubwürdigkeit: Ein Reform-ansatz unter Berücksichtigung konstitutionen- und institutionenökonomischer Aspekte, August 2003

Nr. 18: Ruehmann, Peter: Der deutsche Arbeitsmarkt: Fehlentwicklungen, Ursachen und Reformansätze, August 2003

Nr. 17: Suedekum, Jens: Subsidizing Education in the Economic Periphery: Another Pitfall of Regional Policies?, Januar 2003

Nr. 16: Graf Lambsdorff, Johann; Schinke, Michael: Non-Benevolent Central Banks, Dezember 2002

Nr. 15: Ziltener, Patrick: Wirtschaftliche Effekte des EU-Binnenmarktprogramms, November 2002

Nr. 14: Haufler, Andreas; Wooton, Ian: Regional Tax Coordination and Foreign Direct Investment, November 2001

Nr. 13: Schmidt, André: Non-Competition Factors in the European Competition Policy: The Necessity of Institutional Reforms, August 2001

Nr. 12: Lewis, Mervyn K.: Risk Management in Public Private Partnerships, Juni 2001

Nr. 11: Haaland, Jan I.; Wooton, Ian: Multinational Firms: Easy Come, Easy Go?, Mai 2001

Nr. 10: Wilkens, Ingrid: Flexibilisierung der Arbeit in den Niederlanden: Die Entwicklung atypischer Beschäftigung unter Berücksichtigung der Frauenerwerbstätigkeit, Januar 2001

Nr. 9: Graf Lambsdorff, Johann: How Corruption in Government Affects Public Welfare - A Review of Theories, Januar 2001

Nr. 8: $\quad$ Angermüller, Niels-Olaf: Währungskrisenmodelle aus neuerer Sicht, Oktober 2000

Nr. 7: Nowak-Lehmann, Felicitas: Was there Endogenous Growth in Chile (1960-1998)? A Test of the AK model, Oktober 2000

Nr. 6: Lunn, John; Steen, Todd P.: The Heterogeneity of Self-Employment: The Example of Asians in the United States, Juli 2000

Nr. 5: Güßefeldt, Jörg; Streit, Clemens: Disparitäten regionalwirtschaftlicher Entwicklung in der EU, Mai 2000

Nr. 4: Haufler, Andreas: Corporate Taxation, Profit Shifting, and the Efficiency of Public Input Provision, 1999

Nr. 3: Rühmann, Peter: European Monetary Union and National Labour Markets, September 1999

Nr. 2: Jarchow, Hans-Joachim: Eine offene Volkswirtschaft unter Berücksichtigung des Aktienmarktes, 1999

Nr. 1: Padoa-Schioppa, Tommaso: Reflections on the Globalization and the Europeanization of the Economy, Juni 1999

Alle bisher erschienenen Diskussionspapiere zum Download finden Sie im Internet unter: http://www.uni-goettingen.de/de/60920.html. 